\title{
Effector Mechanisms of Rejection
}

\author{
Aurélie Moreau, Emilie Varey, Ignacio Anegon, and Maria-Cristina Cuturi \\ INSERM UMR 1064, Center for Research in Transplantation and Immunology-ITUN, CHU \\ de Nantes 44093, France \\ Correspondence: ignacio.anegon@univ-nantes.fr
}

Organ transplantation appears today to be the best alternative to replace the loss of vital organs induced by various diseases. Transplants can, however, also be rejected by the recipient. In this review, we provide an overview of the mechanisms and the cells/molecules involved in acute and chronic rejections. T cells and B cells mainly control the antigen-specific rejection and act either as effector, regulatory, or memory cells. On the other hand, nonspecific cells such as endothelial cells, NK cells, macrophages, or polymorphonuclear cells are also crucial actors of transplant rejection. Last, beyond cells, the high contribution of antibodies, chemokines, and complement molecules in graft rejection is discussed in this article. The understanding of the different components involved in graft rejection is essential as some of them are used in the clinic as biomarkers to detect and quantify the level of rejection.

\section{DIFFERENT TYPES OF REJECTION}

Several types of rejection of vascularized orSgans can be defined according to their underlying mechanisms and tempos, the major types being hyperacute, acute, and chronic rejection. In allogeneic context and in the absence of preformed antidonor antibodies, cells and tissues are mainly rejected by acute cellular rejection mechanisms.

Hyperacute rejection appears in the first minutes following transplantation and occurs only in vascularized grafts. This very fast rejection is characterized by vessels thrombosis leading to graft necrosis. Hyperacute rejection is caused by the presence of antidonor antibodies existing in the recipient before transplantation. These antibodies induce both complement activation and stimulation of endothelial cells to secrete Von Willebrand procoagulant factor, re- sulting in platelet adhesion and aggregation. The result of these series of reactions is the generation of intravascular thrombosis leading to lesion formation and ultimately to graft loss. Today, this type of rejection is avoided in most cases by checking for $\mathrm{ABO}$ compatibility and by excluding the presence of antidonor human leukocyte antigen (HLA) antibodies by crossmatch techniques between donor graft cells and recipient sera. This type of rejection is also observed in models of xenotransplantation of vascularized organs between phylogenetically distant species when no immunosuppressive treatment is given to the recipients.

Acute rejection is caused by an immune response directed against the graft and occurs between 1 week and several months after transplantation. Acute rejection is diagnosed on histological analysis of a graft biopsy according to an international classification system, the Banff

Editors: Laurence A. Turka and Kathryn J. Wood

Additional Perspectives on Transplantation available at www.perspectivesinmedicine.org

Copyright (C) 2013 Cold Spring Harbor Laboratory Press; all rights reserved; doi: 10.1101/cshperspect.a015461

Cite this article as Cold Spring Harb Perspect Med 2013;3:a015461 
A. Moreau et al.

classification for the kidney (Mengel et al. 2012). Acute rejection is thought to result from two immunological mechanisms that may act alone or in combination: (1) a T-cell-dependent process that corresponds to acute cellular rejection, and (2) a B-cell-dependent process that generates the acute humoral rejection. With current immunosuppressive treatment, acute rejection occurs in less than $15 \%$ of the transplants (Port et al. 2004) in nonsensitized patients.

Chronic rejection, on the other hand, is now the leading cause of graft rejection. Chronic rejection can be mediated by either humoral or cellular mechanisms linked to memory/plasma cells and antibodies. The presence of tertiary lymphoid organs in the graft is a characteristic of this form of rejection.

\section{INNATE AND ADAPTIVE IMMUNE RESPONSES}

Two major immunological mechanisms occur during allograft rejection: the nonspecific innate response that predominates in the early phase of the immune response, and the donor-specific adaptive response that results from alloantigen recognition by host $\mathrm{T}$ cells.

\section{The Innate Response and Allograft Rejection}

Although the adaptive response plays a central role in the mechanisms of allograft rejection, early proinflammatory signals (arising before the initiation of the T-cell response) are also considered as important factors of graft rejection. Inflammation is caused by the innate immune response induced independently of the adaptive response (Christopher et al. 2002; He et al. 2002, 2003; Land 2005). In fact, it was shown that 1 day after a heart transplant, the expression of genes coding for molecules linked to inflammation (proinflammatory cytokines, chemokines, components of the cellular infiltrate) was similar in normal mice and in mice deficient for T and B cells, but with normal NK and myeloid compartments (Rag1 or Rag2 knock-out mice) (He et al. 2003). These investigators also showed that the innate response is antigen independent, develops early after transplantation, and conditions the development of the adaptive response (He et al. 2003).

Innate immune responses are the consequence of several events associated with clinical transplantation, such as ischemia-reperfusion injury and infections, and lead to the release of damage-associated molecular patterns (DAMPs) and pathogen-associated molecular patterns (PAMPs) (Chong and Alegre 2012). DAMPs and PAMPs are recognized by so-called pattern-recognition receptors (PRRs) expressed by hematopoietic cells.

The specificity of PRRs is genetically determined and several subgroups can be classified based on their structure. The transmembrane group of PRRs includes several families of molecules such as toll-like receptors (TLRs), C-type lectins, RAGE (receptor for advanced glycation endproducts), complement receptors, scavenger receptors, and mannose receptors. The cytosolic PRR group includes retinoic acid-inducible gene-I-like receptors and nucleotide-binding domain and leucine-rich repeat-containing receptors (Iwasaki and Medzhitov 2010).

Immediately after transplantation, PRR-mediated danger signals activate dendritic cells (DCs) (LaRosa et al. 2007) leading to antigenpresenting cell (APC) maturation, up-regulation of costimulatory molecules, and secretion of proinflammatory cytokines. In this context, donor APCs migrate to the T cell areas of secondary lymphoid organs and induce the activation and differentiation of alloreactive naïve $\mathrm{T}$ cells into effector $\mathrm{T}$ helper cells. These effector cells migrate into the graft where they activate macrophages and granulocytes (neutrophils, eosinophils, and basophils) that have infiltrated the graft in response to inflammatory stimuli. The latter cells contribute to lesion formation, either directly or through the production of proinflammatory cytokines and chemokines. They also help boost and maintain the adaptive immune T-cell response. Another cell type involved in innate immunity is the NK cell. In a proinflammatory context, NK cells become activated and are able to kill target cells (Pratschke et al. 2009).

The complement system plays a central role in the effector mechanisms occurring during the innate response. The three complement path- 
ways (classical, alternative, and mannose lectin) can be activated by DAMPs as well as by the inflammatory environment that develops during ischemia reperfusion injury (Castellano et al. 2010). Moreover, the intermediate product of complement, $\mathrm{C} 5 \mathrm{a}$, is able to bind to APC receptors, leading to Th1 activation and development of the adaptive immunity (Zhou et al. 2000).

\section{Initiation of the Adaptive Response and Allograft Rejection}

The adaptive immune response appears later than the innate response, its main characteristic being antigen specific. The initiation of the adaptive response is made possible by the presentation of alloantigens by APCs, mainly DCs and their allorecognition by recipient $\mathrm{T}$ cells. Three main pathways of allorecognition are described in the literature. The first is the direct pathway, in which donor DCs present in the graft act as passenger leukocytes. In the context of a proinflammatory environment, these cells mature and migrate to secondary lymphoid organs where they prime host T cells. The maturation of these cells is induced by proinflammatory signals such as IL- $1 \beta$, TNF- $\alpha$, and CD40. The second is the indirect allorecognition pathway in which recipient DCs capture, process, and present alloantigens as peptides on their host MHC molecules, and then prime $\mathrm{T}$ cells (Ochando et al. 2006). As dendritic cells express both MHC class I and class II, donor antigens can be presented to either $\mathrm{CD}^{+}$or $\mathrm{CD}^{+} \mathrm{T}$ cells. The third pathway is that of semidirect allorecognition, characterized by the dual ability of recipient DCs: (1) to present intact donor major histocompatibility complex (MHC) molecules acquired by cell-to-cell contact or fusion with donor exosomes, and (2) to internalize and process donor $\mathrm{MHC}$ as peptides on recipient $\mathrm{MHC}$ molecules. In this pathway, alloreactive $\mathrm{CD} 8^{+}$ and $\mathrm{CD} 4^{+} \mathrm{T}$ cells are stimulated by direct and indirect allorecognition (Herrera et al. 2004; Smyth et al. 2006).

Using the two-photon microscopy technique, a recent elegant study by Bousso's group (Celli et al. 2011) provided a better understanding of the adaptive immune response by clarify- ing several different issues that until then had remained hypothetical. In a murine model of skin transplantation, they showed that donor dermal DCs disappeared rapidly from the graft and migrated to draining lymph nodes (LNs). However, these donor DCs were found to be dead in the secondary lymphoid organs. This is consistent with a previous study demonstrating that donor DCs are eliminated by NK cells (Garrod et al. 2010). It has been suggested that these dying cells could be a source of alloantigens for recipient APCs present in the draining LNs that stimulate $\mathrm{T}$ cells by the indirect pathway. Moreover, these experiments showed that host inflammatory monocytes and DCs act as antigen-transporting cells. These recipient graft-infiltrating cells indeed have the ability to reach the draining LNs and cross-prime $\mathrm{CD}^{+} \mathrm{T}$ cells by the indirect pathway (Celli et al. 2011).

Initiation of the innate and adaptive immune response leads to acute and chronic graft rejection. Cellular and humoral responses, but also chemokines and innate cells, are present in both types of rejection and are described in this article.

\section{ACUTE REJECTION}

\section{The Components of Acute Rejection}

\section{Chemokines}

Chemokines are chemoattractant cytokines that influence immune cell migration. In transplantation settings, chemokines act during four key phases: (1) recruitment of mononuclear cells to the site of inflammation, (2) migration of APCs to draining LNs, (3) interaction between unprimed T cells and APCs in LNs, and (4) migration of primed alloreactive $\mathrm{T}$ cells to the graft (Belperio and Ardehali 2008). The roles of some chemokines in allograft rejection have been investigated directly by analyzing chemokine expression by immune cells as described in Figure 1. Furthermore, the function of these chemokine receptors and ligands has been shown using knockout $(\mathrm{KO})$ mice or blocking antibodies.

One example is that of CCR5, which was shown to be expressed by mononuclear cells, 
A. Moreau et al.

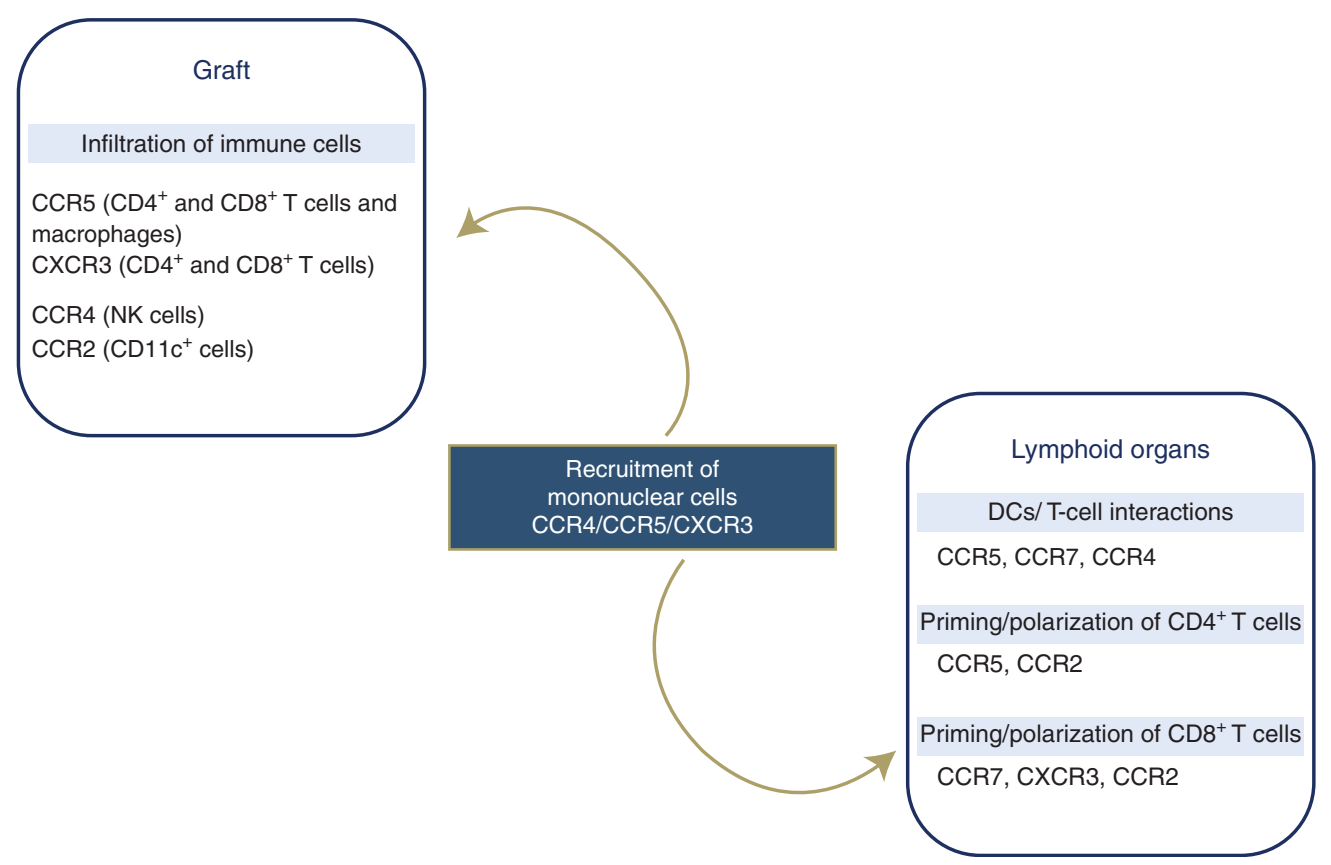

Figure 1. Chemokines: Homing of immune cells and role in acute rejection. Mononuclear cells are able to migrate into the graft or into the lymphoid organs in response to chemokine gradients. Experiments on animal models of transplantation and analysis of human samples from transplant recipients allow a better understanding of the involvement of chemokines in graft rejection.

suggesting that this chemokine helps their migration to inflammatory sites. Prolongation of cardiac allograft survival was obtained in $\mathrm{CCR}^{-/-}$mice, demonstrating a major role for this chemokine (Gao et al. 2001). However, more recently, in a similar heart transplant model, Nozaki et al. (2007) only detected a modest effect of CCR5 on graft rejection using CCR5 ${ }^{-/-}$ mice. Involvement of CCR5 in graft rejection was also shown in murine models of pancreatic islet transplantation (Abdi et al. 2002). More recently, in a cardiac transplantation model in rhesus monkeys, cotreatment with a CCR5 antagonist and cyclosporine A was able to prolong heart survival. This prolongation was associated with a delay in alloantibody response, a lower graft infiltration, and a decrease in alternatively activated macrophages (Li et al. 2011). In addition to the recruitment of mononuclear cells to the graft, CCR5 polarizes $\mathrm{T}$ cells toward a type 1 response, and promotes the trafficking of $\mathrm{T}$ cells to LNs and favors DC/T-cell interaction within the LNs (Amano et al. 2005). Furthermore,
Y-box protein-1, a molecule that acts as a transcription regulator of CCL5, one CCR5 ligand also called RANTES, expression in T cells, and monocytes/macrophages, was shown to be upregulated during rejection in human kidney transplant biopsies (Raffetseder et al. 2009). Contrary to these studies, in a rat model of kidney transplant tolerance following CD28 blockade, CCL5 recruited CD $4{ }^{+}$Tregs to the graft via a graft-to-periphery CCL5 gradient (Dilek et al. 2012).

Another well-described chemokine involved in graft rejection is CXCR3. In a murine model, absence of CXCR3 in graft recipients was shown to prolong cardiac transplant survival (Hancock et al. 2000). However, as for CCR5, a more recent study obtained controversial results showing no delay in graft rejection between controls and CXCR3 KO mice (Kwun et al. 2008). Analysis of CXCR3 and its ligands, CXCL9 and CXCL10, was performed in biopsies from transplant patients undergoing acute rejection. Fahmy et al. (2003) showed an up-regulation 
of CXCL10 in endomyocardialbiopsies, whereas an increase in CXCL10 was detected in macrophages of lung biopsies (Agostini et al. 2001). Furthermore, the number of $\mathrm{CXCR}^{+}$cells present in human kidney transplant biopsies was reported to increase with graft rejection and to decrease with immunosuppressive treatment, suggesting that CXCR3 might be a good target to treat rejection (Hoffmann et al. 2006). Other recent studies have highlighted the role of chemokines as biomarkers of clinical rejection and are described in Table 1.

In mouse models of cardiac and pancreatic islet transplantation, expression of CXCR3 was detected in Tregs, memory $\mathrm{CD} 4^{+}$and $\mathrm{CD}^{+}{ }^{+} \mathrm{T}$ cells, NKT, and NK cells (Uppaluri et al. 2008). Zhai et al. (2006) showed that CXCR3 is involved in the recruitment of $\mathrm{CXCR}^{+}{ }^{+} \mathrm{CD} 4^{+} \mathrm{T}$ cells following ischemia-reperfusion injury in a model of rat syngeneic orthotopic liver transplantation. Similarly, expression of CXCR3 by Tregs resulted in their recruitment to peripheral sites of inflammation, and a high number of circulating CXCR $3^{+}$Tregs was detected in kidney transplant patients treated with an mTOR inhibitor as their immunosuppressive therapy (Hoerning et al. 2011). In addition to the role of CXCL9/ CXCL10 in the recruitment of $\mathrm{T}$ cells to the allograft, Rosenblum et al. (2010) recently showed that these chemokines regulate donor-specific $\mathrm{CD}^{+}{ }^{+} \mathrm{T}$-cell priming. As such, in a murine model of cardiac transplantation using $\mathrm{KO}$ mice for either the CXCL9 or CXCL10 gene, CXCL9 promoted, whereas CXCL10 inhibited the differentiation of IFN- $\gamma$-producing donor-specific $\mathrm{CD}^{+} \mathrm{T}$ cells.

A new molecule called TAK-779 was identified as a blocking agent for both CCR5 and CXCR3. This molecule was shown to prevent cardiac allograft rejection in mice (Akashi et al. 2005) as well as kidney rejection in rats (Kakuta et al. 2012). In the latter study, prolongation of graft survival correlated with a decrease in macrophage infiltration (Kakuta et al. 2012). Last, coexpression of CXCL10 and fractalkine or CX3CL1 by endothelial cells was shown to be involved in effector memory T-cell recruitment (Manes et al. 2007; Manes and Pober 2008). Fractalkine acts as a chemoattractant and adhe- sion molecule for cells that express CX3CR1, including certain immune cells such as monocytes/macrophages, NK cells, and T cells (Imai et al. 1997; Fong et al. 1998; Foussat et al. 2000).

Some studies have also been performed to analyze other chemokine receptors. For example, CCR2 was shown to be an important chemoattractant receptor for mononuclear cells. This is because CCR2 induced mobilization of monocytes from bone marrow to blood and an accumulation of CD11 $c^{+}$cells in the allograft in a mouse model of lung allotransplantation (Gelman et al. 2010). Interaction of CCR2 with its ligand (CCL2) also caused T-cell clonal expansion and differentiation (Lee et al. 2003). In CCR $2^{-/-}$mice, an increase in graft survival was observed after pancreatic islet transplantation (compared to control mice) and associated with the absence of $\mathrm{CD}^{+}{ }^{+}$effector T cells in these mice (Abdi et al. 2004).

CCR4 is an important chemokine for homing of memory T cells (Campbell et al. 1999) and was shown to be crucial for the recruitment of FoxP $^{+}$Tregs in a model of tolerance induced by donor-specific transfusion/CD154 therapy (46) as no tolerance was achieved in CCR4-deficient mice (Lee et al. 2005). Inhibition of CCR4 and its ligands led to an increase in heart graft survival associated with a decreased in DC/T-cell interactions and an inhibition of monocytes and NK cells present in the graft (Alferink et al. 2003; Huser et al. 2005). Last, CCR7 is known to be involved in the localization of both DCs and T cells in the T-cell-rich zones of the LNs, indicating a role for CCR7 in T-cell homing and priming (Hopken et al. 2004). Recently, Liu et al. (2011) showed that a lack of CCR7 prevented tolerance induction in a cardiac murine model of transplantation. This impairment of tolerance was partially rescued by adoptive transfer of wild-type plasmacytoid DCs to the CCR7deficient mice (Liu et al. 2011).

As discussed before, some of these chemokines and chemokine receptors might be useful as markers of acute rejection. In the case of renal transplantation, rejection could be monitored via noninvasive urine sampling. The most wellknown urine marker is IP-10 or CXCL10. An increase in IP-10 mRNA and protein in the 
A. Moreau et al.
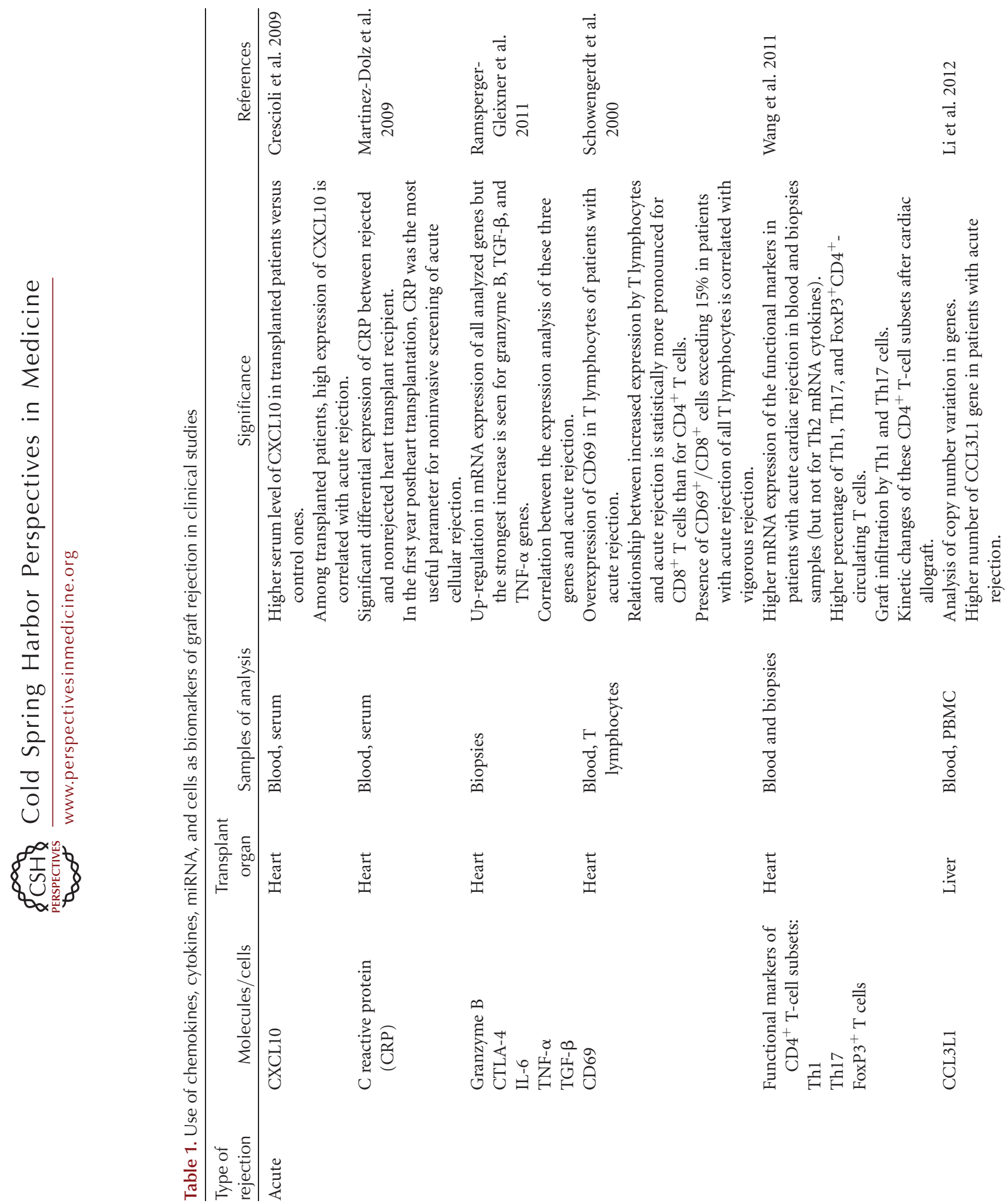
Effector Mechanisms of Rejection
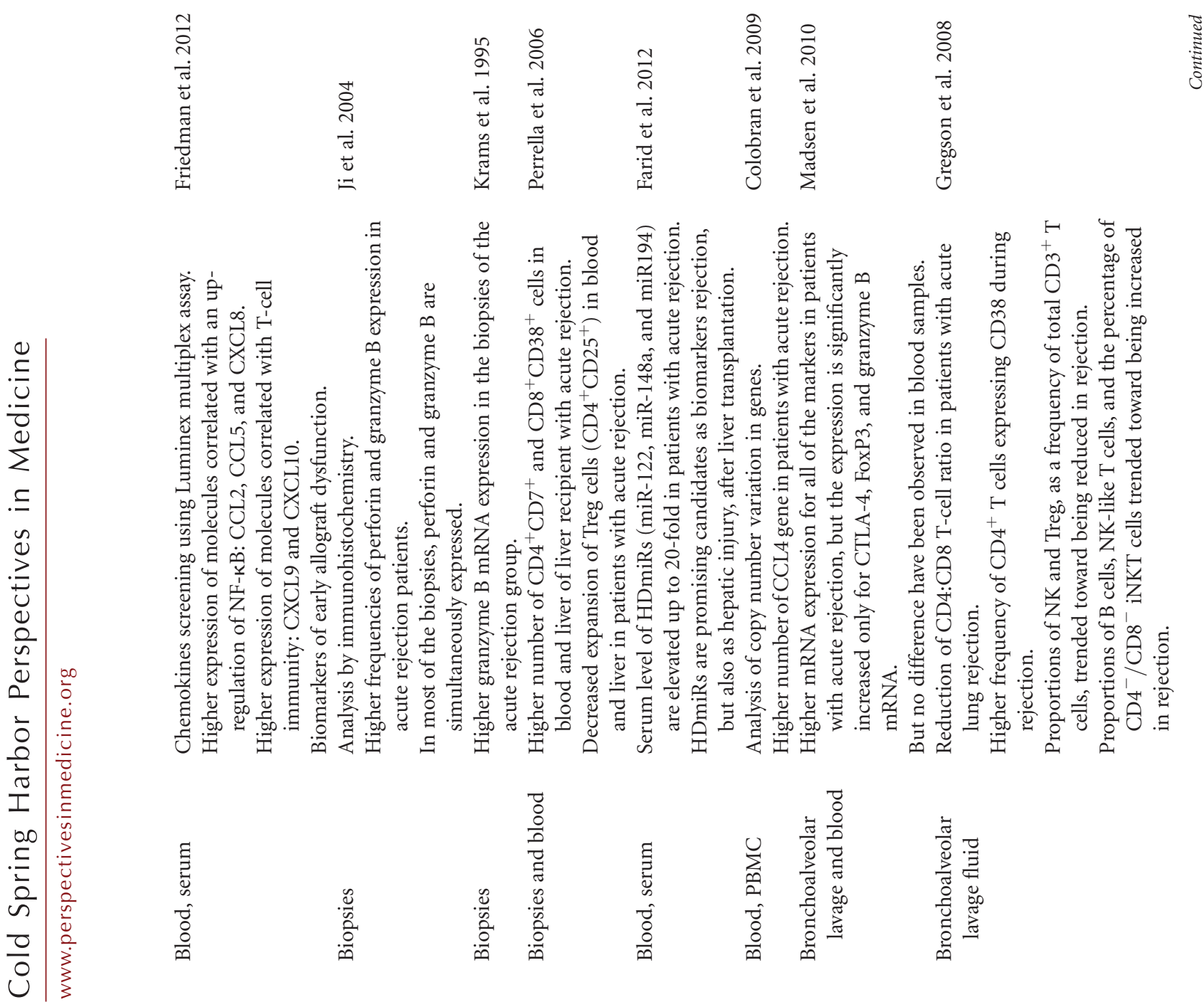

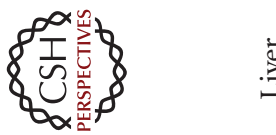
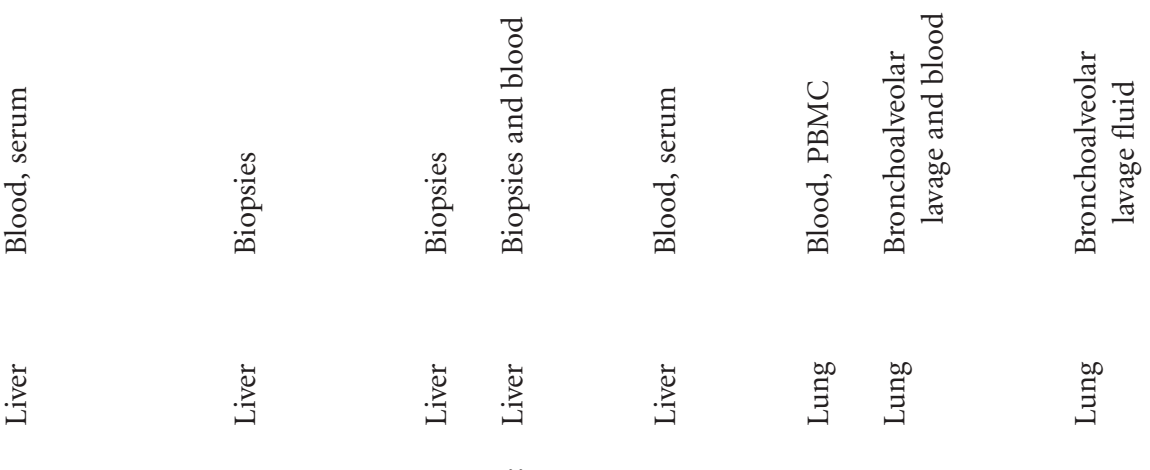

$\stackrel{\infty}{\Xi} \underset{\Xi}{\Xi}$

$\stackrel{\infty}{\Xi}$
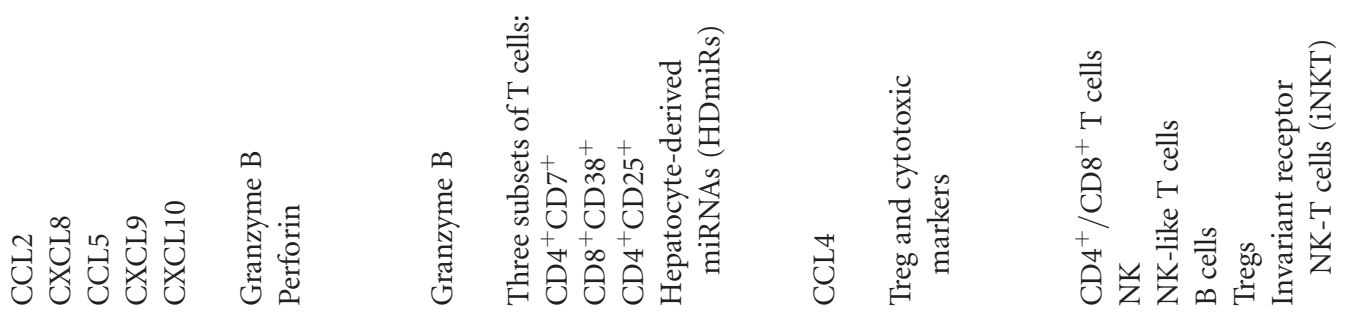

㫕 
A. Moreau et al.
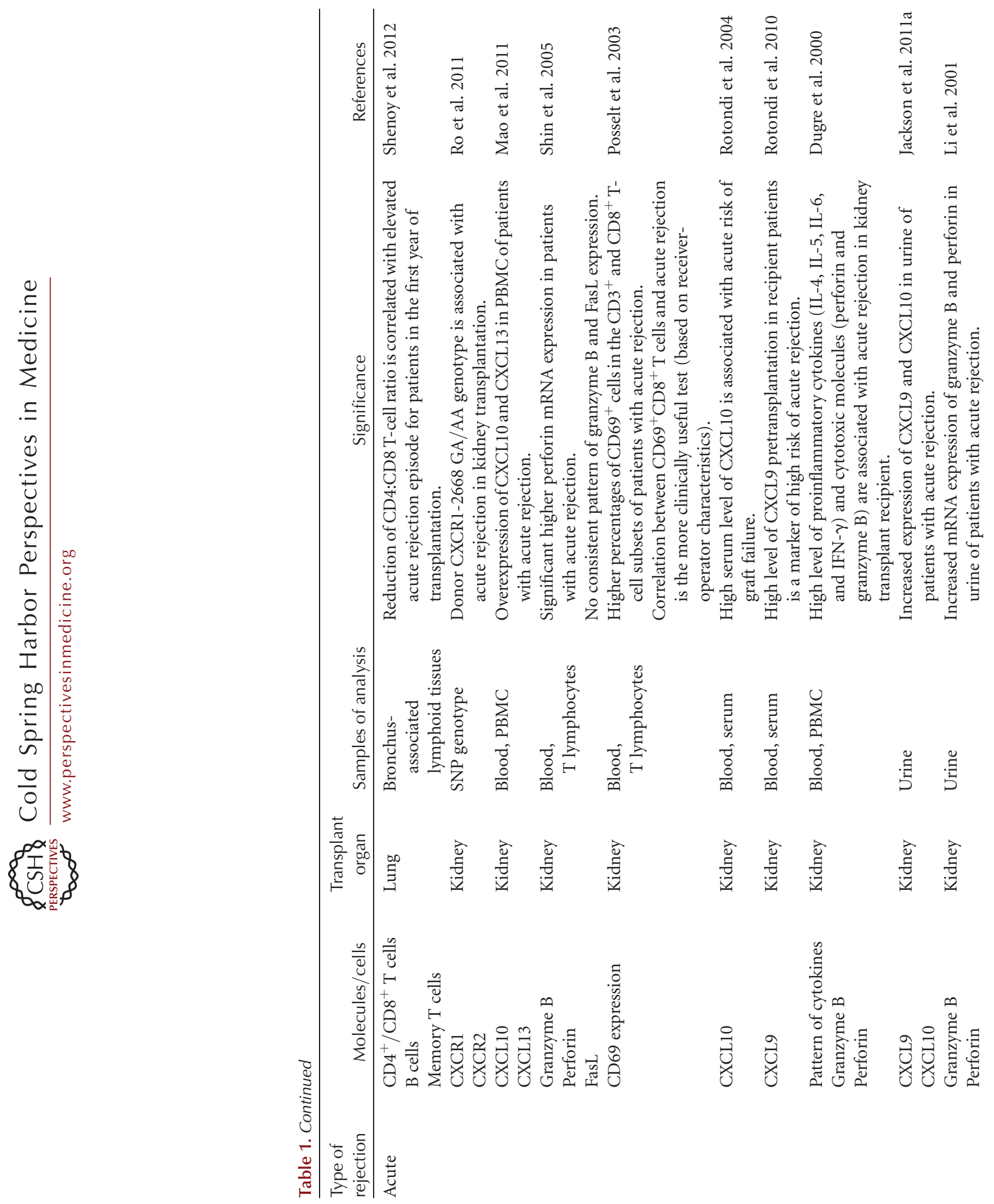

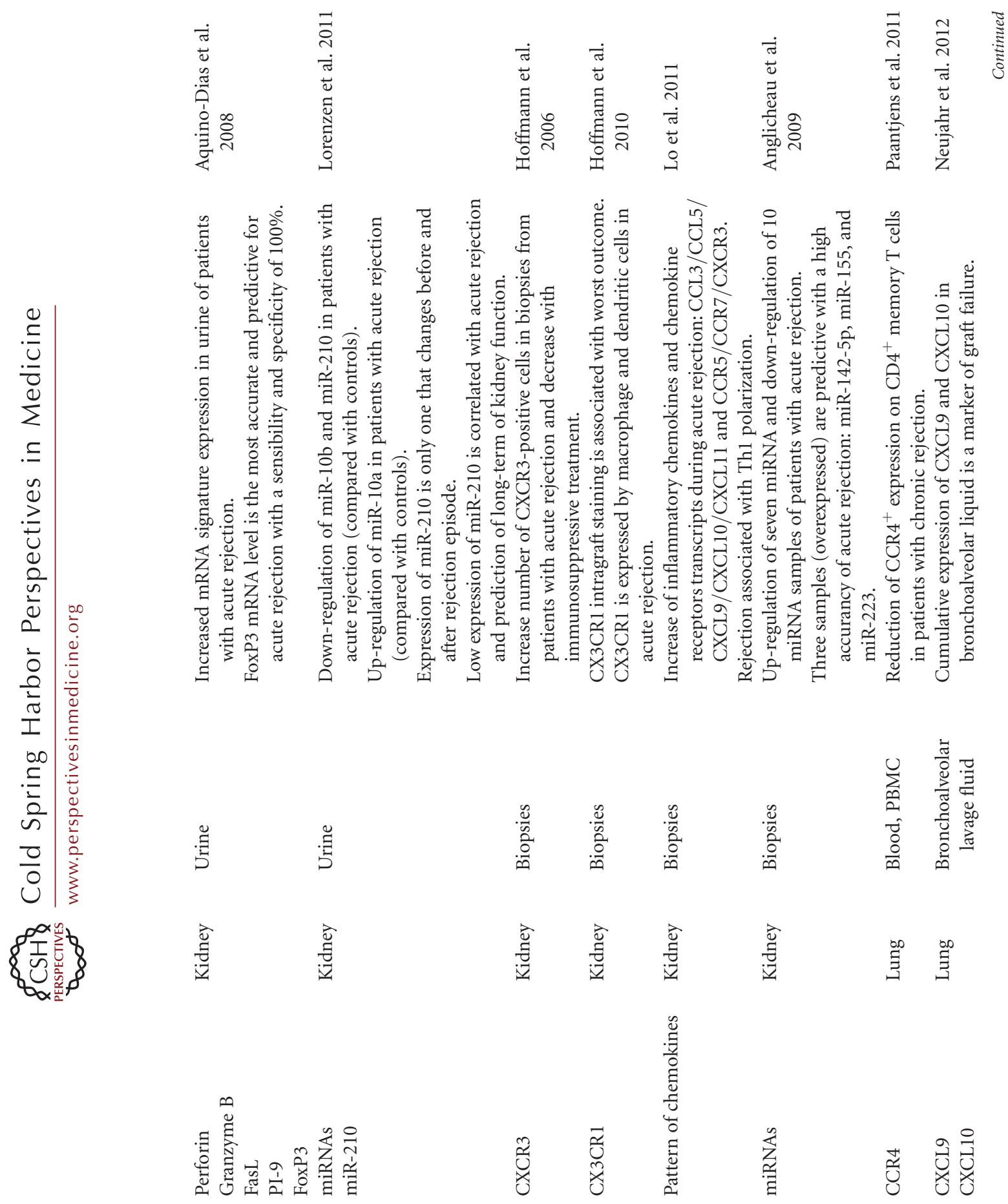

ঊ<smiles>C#CC1CC1</smiles> 
A. Moreau et al.
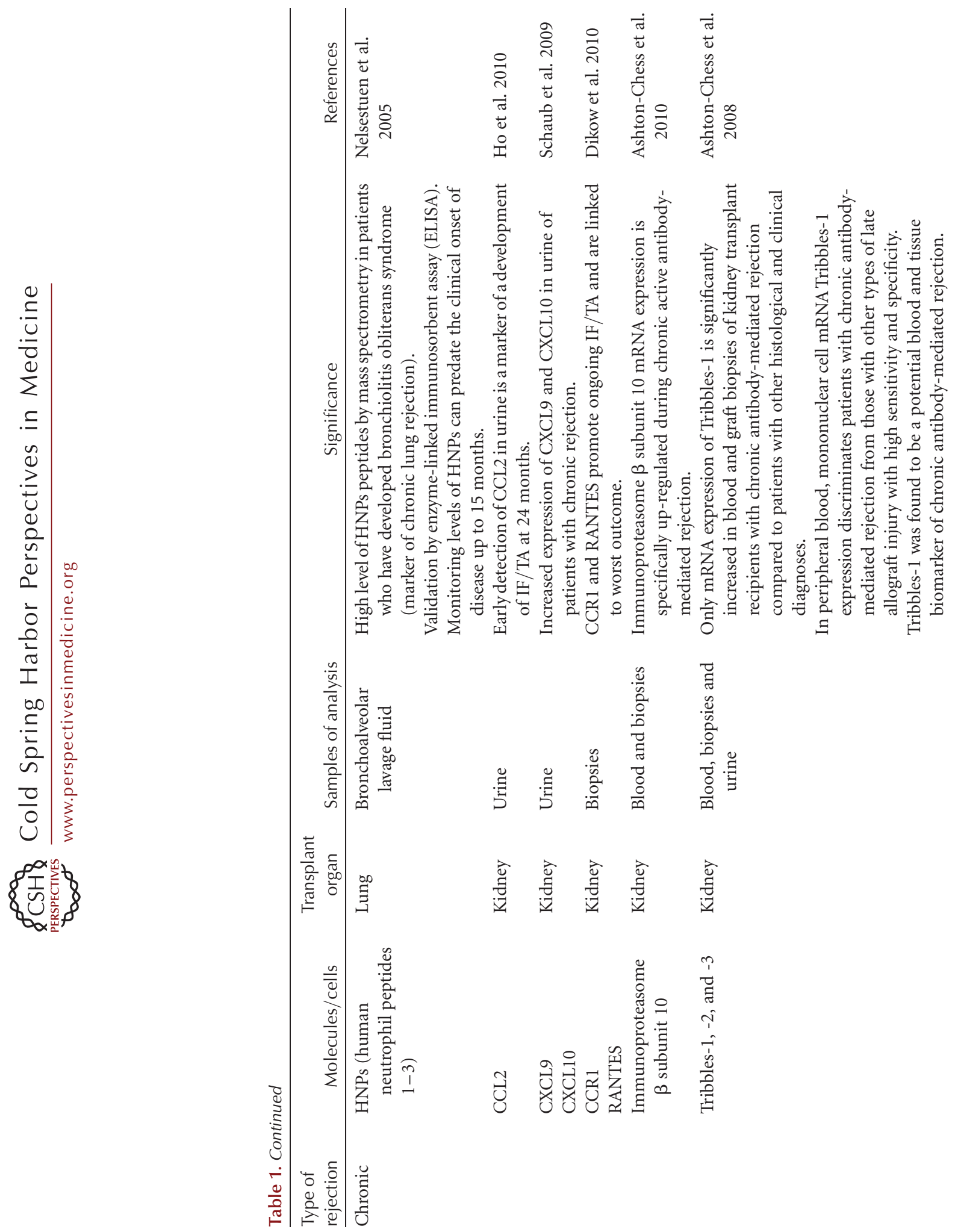
Effector Mechanisms of Rejection
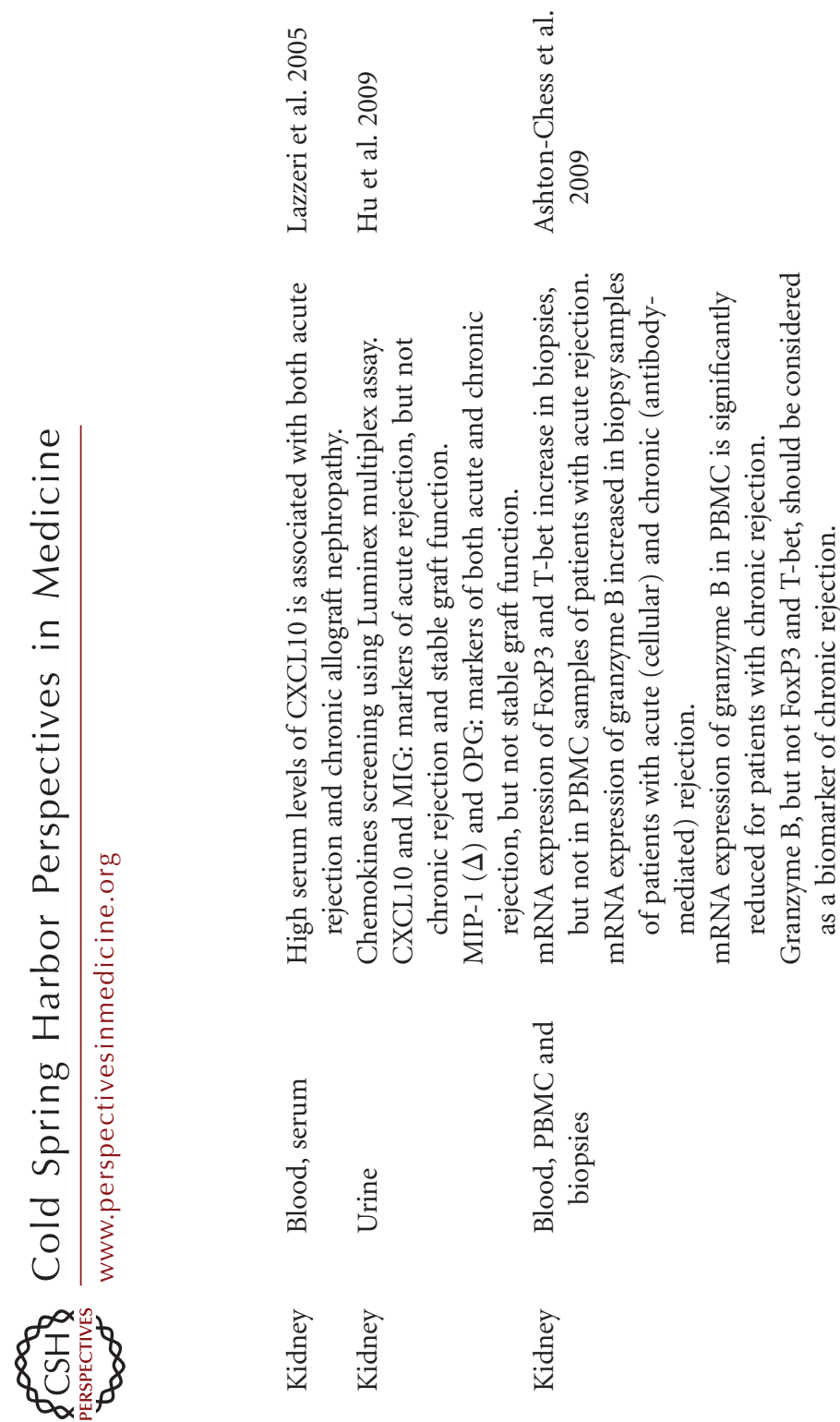

光
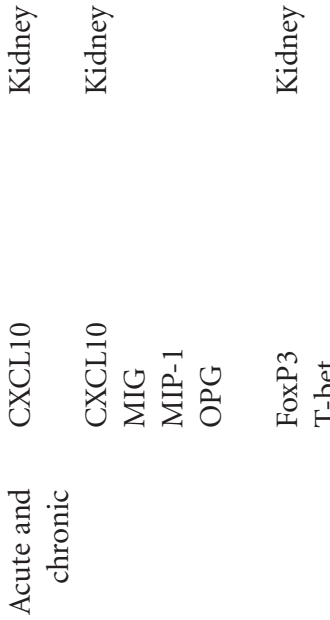
A. Moreau et al.

urine of a kidney transplant recipient was shown to correlate with incidence of acute rejection episodes (Matz et al. 2006). Moreover, high levels of CXCL3 (Tatapudi et al. 2004) and CD103 mRNA (Ding et al. 2003) were present in a recipient undergoing acute rejection. Nevertheless, chemokines are not the only markers of rejection. In fact, other proteins, such as granzyme B and FoxP3, miRNAs, and cells could also be used as predictive biomarkers of rejection (Table 1).

\section{Nonspecific Effector Cells (NK Cells, Macrophages, Monocytes, DCs, and Neutrophils)}

Despite the finding that NK cell detection in the graft infiltrate was a negative prognostic factor (Sorrentino et al. 2006), this cell type does not appear to be necessary or sufficient to mediate allograft rejection. Some recent studies have even highlighted the involvement of NK cells in the phenomenon of tolerance (van der Touw et al. 2012). NK cells seem to act mainly as a bridge between innate and adaptive immune responses. This has been underlined by experiments using CD28-deficient mice. For example, by depleting NK1.1 ${ }^{+}$cells using antibodies in CD28-deficient mice, some groups showed that absence of NK cells reduce cardiac allograft rejection in mice (Maier et al. 2001; McNerney et al. 2006). In this model, NK cells, but not NKT cells, were required for rejection by promoting $\mathrm{T}$ cell expansion and effector function (McNerney et al. 2006). This effect was independent of the NK-cell activator NKG2D receptor.

In contrast, several studies have highlighted the role of the NKG2D receptor in rejection. In a model of cardiac transplantation in CD28-deficient mice, blocking NKG2D prevented graft rejection (Kim et al. 2007). Zhang and coworkers confirmed the involvement of NKG2D in graft rejection as they showed that the NKG2D receptor present on NK cells recognizes renal tubular epithelial cells, leading to their killing by a perforin-dependent pathway during ischemia reperfusion injury (Zhang et al. 2008). Promotion of $\mathrm{CD}^{+}{ }^{+} \mathrm{T}$-cell activation by the indirect allorecognition pathway is another mechanism of action of NK cells investigated by NK-cell depletion and NKG2D blockade in a murine skin graft model (Ito et al. 2008). Two ligands of NKG2D, namely RAEL1 and RRLT, were found to be expressed in rat liver allograft and to be linked to acute rejection (Zhuo et al. 2010). Moreover, in human kidney transplant biopsies, an elevated level of NKG2D mRNA was also associated with acute rejection (Seiler et al. 2007). NK cells produce a variety of cytokines, including IFN- $\gamma$, TNF- $\alpha$, and TGF- $\beta$, as well as colony-stimulating factors (Cuturi et al. 1987, 1989; Anegon et al. 1988). IFN- $\gamma$ produced by NK cells is known to induce an up-regulation of MHC class I and class II molecules by endothelial cells leading to their killing by $\mathrm{CD} 8^{+} \mathrm{T}$ cells (McDouall et al. 1997; Ayalon et al. 1998). More recently, a role for IL-15 in NK-cell-mediated mechanisms was shown, as in vivo stimulation of NK cells with IL-15 was found to induce skin graft rejection in $\mathrm{RAG}^{-/-}$mice (Kroemer et al. 2008). Last, an interesting effect of NK cells on donor DCs has been described. Coudert et al. (2002) showed that interaction of NK cells with donor DCs in the absence of $\mathrm{CD}^{+} \mathrm{T}$ cells promoted $\mathrm{CD}^{+}{ }^{+} \mathrm{T}$-cell priming and regulated the Th balance. In a more recent study performed in a model of $\mathrm{CD}^{+}$T-cell-mediated allogeneic skin graft rejection, NK cells killed donor DCs in draining LNs by a perforin-dependent pathway that avoided T-cell activation (Laffont et al. 2008) thereby confirming that NK cells favor indirect allorecognition (Garrod et al. 2010).

Macrophages constitute another innate cell population that contributes to the tissue damage observed in rejected organs. In humans, macrophages were found to represent $40 \%-$ $60 \%$ of the cellular infiltrate in renal allotransplants (Hancock et al. 1983). A large number of monocytes were also detected in infiltrates from the graft biopsies of kidney transplant recipients under T-cell-depleting therapy (antiCD52 and FK506 monotherapy) (Salama et al. 2007). These cells were recruited to inflammatory sites by monocyte chemoattractant protein-1 (MCP-1). Blockade of MCP-1 was shown to increase pancreatic islet transplant survival in rodents (Lee et al. 2003). In addition, blockade of macrophage colony-stimulating factor- 
reduced macrophage proliferation and accumulation in the graft leading to a decrease in the severity of kidney transplant rejection in mice (Jose et al. 2003). Other studies have confirmed in macrophages a decreased infiltration and an increase in graft survival in murine models of both kidney (Qi et al. 2008) and heart (Takeiri et al. 2011) transplantation. Furthermore, in the context of human kidney transplantation, CX3CR1 expression by macrophages was associated with acute rejection, and was a negative prognostic factor in human kidney graft (Hoffmann et al. 2010).

There are several macrophage subsets, and specialized tissue-resident macrophages are widely distributed across the body including the liver (Kupffer cells) and bone (osteoclasts). Macrophages can also display heterogeneity in terms of their functional phenotype as well as their activation state. In the same terms, activated macrophages are classified as classically or alternatively activated macrophages, named M1 and M2 macrophages, respectively, referring to T-cell nomenclature (Mantovani et al. 2004).

M1 macrophages are activated by a combination of IFN- $\gamma$ and TNF released by Th1 cells. M1 macrophages have the capacity to present antigen to $\mathrm{T}$ cells and express high levels of costimulatory molecules (CD86 and CD80) (Mantovani et al. 2004). These cells also express large amounts of the proinflammatory cytokine IL-12 and promote the development of the Th17 immune response by secreting IL-1, IL-6, and IL-23. M1 macrophages are thought to play a role in the defense against bacteria or viruses as well as tumor resistance. However, in several conditions, this macrophage subset can take part in chronic inflammation and autoimmune diseases (Mosser and Edwards 2008).

M2 macrophages, on the other hand, are associated with immunoregulation. Macrophage phenotype and function are thought to differ according to the chemokine environment at the time of their activation (Mantovani et al. 2004). In fact, macrophages develop a regulatory profile when activated by IL-10 or immune complexes associated with a second stimulus. These cells act as regulatory cells by producing high levels of IL-10 and other anti-inflammatory cy- tokines such as TGF- $\beta$, for example (Mosser and Edwards 2008). Alternatively, if resident macrophages are activated in the presence of IL- 4 and IL-13, they are considered as M2a, or woundhealing macrophages, as they promote tissue repair. The latter cells are characterized by an upregulation of mannose receptor and production of polyamine (Mantovani et al. 2004; Mosser and Edwards 2008).

However, depending on the context, activated macrophages are able to switch their phenotype and change their function too (Mosser and Edwards 2008). One example of this is the differentiation of M1 to hybrid macrophages that share the characteristics of both regulatory and wound-healing macrophages. Unfortunately, these cells are tumor-associated macrophages and inhibit antitumor immunity (Duluc et al. 2007). Another example is in the context of the autoimmune disease diabetes, in which adiposetissue-associated macrophages with a woundhealing phenotype polarize toward a phenotype similar to classically activated macrophages (Lumeng et al. 2007).

A recent study performed in a rat model of lung transplantation showed that $\mathrm{CD}^{+} 8^{+}$macrophages were the most abundant cell type observed during acute rejection, whereas CD163 ${ }^{+}$ cells were distributed around vessels and bronchioles (Jungraithmayr et al. 2010). Regarding their tissue localization, macrophage infiltration was significant in the interstitium, but also in the arterial intima of vascularized grafts (Sun et al. 2011). Infiltration was also observed in the glomeruli of kidney transplants.

In contrast to the arterial intima in which no correlation between antibody-mediated rejection (AMR) and macrophage infiltration was shown (Kozakowski et al. 2009), macrophages / monocytes were associated with AMR when present in the glomeruli. Moreover, presence of focal or diffuse C4d deposits was associated with macrophage/monocyte infiltrates, whereas $\mathrm{T}$ cells predominated when no C4d deposits were detected (Magil 2005; Magil and Tinckam 2006). These results were confirmed by Fahim et al. (2007), who showed an abundant recruitment of monocytes to peritubular and glomerular capillaries during humoral rejection. More- 
A. Moreau et al.

over, in a murine model of hepatocellular allotransplantation in which rejection is mediated by a CD4-dependent alloantibody response, depletion of macrophages delayed hepatocyte rejection and inhibited in vivo allocytotoxicity (Horne et al. 2008).

Polymorphonuclear cells are also efficient producers of chemokines (Molesworth-Kenyon et al.2005). As described in the previous section, chemokines act on T-cell activation, proliferation, and function. One type of polymorphonuclear cell, the neutrophil, was detected in large numbers among the cells infiltrating murine skin allografts during acute rejection (Celli et al. 2011). Neutrophils have also been shown to contribute to allograft rejection in models of costimulation blockade (El-Sawy et al. 2005), or in the absence of IFN- $\gamma$ (Miura et al. 2003) and IL-4 (Surquin et al. 2005). There is also evidence of eosinophil involvement in models of rejection and their activation was shown to be dependent on a Th2 $\mathrm{CD} 4{ }^{+} \mathrm{T}$-cell response (IL4-dependent) (Braun et al. 2000; Surquin et al. 2005). Eosinophils were also abundant in intestinal graft infiltrates on T-cell elimination ( $\mathrm{Wu}$ et al. 2006).

Recently, the role of platelets has been shown in allograft rejection, as these cells are able to induce immune stimulation. In this context, platelets are believed to act by recruiting mononuclear cells by secreting cytokines/chemokines and by stimulating monocytes, macrophages, and $\mathrm{T}$ cells by interaction with them via $\mathrm{P}$-selectin/PSGL-1 or CD40/CD40L pathways (Xu et al. 2006; Kirk et al. 2009).

Last, endothelial cells are also able to induce allogeneic $\mathrm{CD}^{+}$and $\mathrm{CD}^{+}{ }^{+}$T-cell activation and proliferation, favoring IFN- $\gamma$ and IL-2 secretion and leading to graft rejection (Epperson and Pober 1994). In a recent review, Taflin et al. (2011, 2012) described how in the context of inflammation, such as observed in transplantation, endothelial cells are activated by proinflammatory cytokines and TLR ligands. This activation leads to memory $\mathrm{CD}^{+}{ }^{+} \mathrm{T}$-cell proliferation and Th1/Th17 expansion by endothelial cell secretion of proinflammatory cytokines and chemokines (such as CXCL10, IL-6, and IL-1 $\alpha$ ) and overexpression of costimulatory molecules (such as LFA-3 or OX-40L) or adhesion molecules (such as ICAM-1) (Griffin et al. 2012). In humans, three nonclassical MHC class I antigens exist: HLA-E, HLA-F, and HLA-G. Coupel et al. (2007) showed that HLA-E is expressed only by leukocytes, such as NK cells, B and T lymphocytes, macrophages, and by endothelial cells. Moreover, they show that endothelial cells up-regulate HLA-E in inflammatory conditions, and endothelial cells produce a soluble form of HLA-E. Coupel's group additionally showed that increased expression of the membrane-bound form of HLA-E protected IFN- $\gamma$ activated endothelial cells from CD94/NKG2Amediated cytolysis, whereas the soluble form of HLA-E protected other cell types. Endothelial cells expressed the MHC class-I related chain A, MICA, which is a ligand for NKG2D. NK cells and cytotoxic T cells express this activating receptor. Under inflammatory stimulation by TNF- $\alpha$, human endothelial cells up-regulate the expression of MICA (Lin et al. 2012). These results are consistent with previous data suggesting that MICA is expressed by kidney macrovascular endothelial cells in kidney transplant recipients (Sumitran-Holgersson et al. 2002). Moreover, this study showed that MICA acts as an antibody target, which confirmed anti-MICA antibodies are associated with the reduction of graft survival (Zou et al. 2007).

\section{Acute Cellular Response \\ T-Cell Activation and Effector T Cells}

Effector T cells can mediate cell lysis either via cytokine or chemokine secretion, which induces necrosis of transplant tissue, or via direct contact with epithelial or endothelial cells and various mechanisms of cytotoxicity. However, T cells can also stimulate B cells to initiate humoral rejection, or other cells such as macrophages or neutrophils, whose role in transplant rejection is described above.

On activation by DCs, naïve alloreactive $\mathrm{CD} 4^{+}$T cells can differentiate into Thelper cells, including Th1, Th17, Th2, or into regulatory $\mathrm{T}$ cells (Tregs). In a proinflammatory environment, naïve $\mathrm{CD} 4^{+} \mathrm{T}$ cells differentiate mainly 
into Th1 and Th17 cells. Th1 cells produce IFN$\gamma$ and IL-2 and are involved in cytotoxic T lymphocyte (CTL) priming, stimulation of the humoral response, and activation of other cell types such as NK cells. IL-17 produced by Th17 cells stimulates the production of inflammatory cytokines and chemokines leading to the recruitment of neutrophils and macrophages to the graft. In a Th1-depleted environment, Th17 cells (Yuan et al. 2008) or Th2 cells (Barbara et al. 2000) can efficiently promote graft rejection. Th2 cells release anti-inflammatory cytokines such as IL-10 and IL-4 T follicular helper cells and Th9 helper cells have not yet been described in detail, but they have been shown to induce Bcell maturation and mast cells recruitment, respectively.

In contrast, $\mathrm{CD} 4^{+}$Tregs have been shown to be involved in the tolerance process and to prevent graft rejection in mice (Kingsley et al. 2002). These cells are able to suppress $\mathrm{CD} 4^{+}$and $\mathrm{CD} 8^{+}$ effector T cells and can also target APCs, decreasing their capacity for antigen-presentation and costimulation (Shevach 2009). A recent study performed using humanized mice showed the superiority of donor alloantigen-specific $\mathrm{CD} 4^{+}$ Tregs over their polyclonal counterparts to suppress alloimmune responses (Sagoo et al. 2011). In tolerant liver transplant patients, an increase in peripheral blood $\mathrm{CD}^{+}$Tregs has been observed by several groups (Li et al. 2004; Martinez-Llordella et al. 2007; Pons et al. 2008; Nafady-Hego et al. 2010). Although this Treg signature does not seem to be present in the peripheral blood of kidney transplant patients, an increase in intragraft Tregs was detected in such patients (Bestard et al. 2007).

$\mathrm{CD}^{+} \mathrm{T}$ cells can differentiate into CTLs, which themselves can be classified as Tc1, Tc2, or the more recently described Tc17 (Yuan et al. 2009). Although, naïve $\mathrm{CD}^{+}$cells can only be activated by $\mathrm{DCs}, \mathrm{CD} 4^{+} \mathrm{T}$ cells have been shown to facilitate $\mathrm{CD} 8{ }^{+} \mathrm{T}$-cell differentiation either by cell-to-cell contact or by secretion of IL-2/IFN$\gamma$ cytokines. In the latter case, both APCs and $\mathrm{CD}^{+}$helper $\mathrm{T}$ cells have been shown to be involved in CTL differentiation (Ridge et al. 1998). CTLs subsequently migrate to the graft where they recognize target cells via their allogeneic
MHC class I molecules. Killing by CTLs is mediated mainly by the secretion of perforin and granzyme B, or by the Fas/FasL pathway. These two pathways induce target cell apoptosis. CTLs are also able to secrete soluble mediators such as TNF- $\alpha$. In terms of the dynamics of CTL action, in a model of skin graft rejection, an accumulation of CTLs surrounding the graft was detected, followed by an early phase of killing in small areas of the dermis/epidermis junction. The CTLs were shown to disseminate to the whole graft and induce tissue destruction (Celli et al. 2011).

Compared to their naïve counterparts, memory $\mathrm{T}$ cells induce a faster and more effective immune response with lower antigen stimulation (Rogers et al. 2000; Veiga-Fernandes et al. 2000). This is supported by data in humans showing that the pretransplant frequency of donor-specific memory cells correlates with the posttransplant risk of developing acute rejection episodes (Heeger et al. 1999). These results were confirmed in liver transplant patients in whom the presence of a high number of $\mathrm{CD}^{+}$cells with a memory phenotype before transplantation was associated with reduced graft survival (Tanaka et al. 2006). More recently, in a model of kidney allotransplantation in nonhuman primates, Nadazdin et al. (2011) showed that the presence of memory $\mathrm{T}$ cells before transplantation was a barrier to transplantation tolerance.

Despite $\mathrm{CD}^{+}$Tregs being of considerable interest in transplantation, their subsets and mechanisms of action are less understood in comparison to their $\mathrm{CD}^{+}$Treg counterparts (Guillonneau et al. 2010). Understanding the function and mechanisms of action of the different $\mathrm{CD} 8^{+}$Treg subsets is essential. In rodent models, several studies have shown the role of $\mathrm{CD}^{+}{ }^{+}$Treg subsets in the suppression of transplant rejection. For example, donor-antigenspecific $\mathrm{CD} 8{ }^{+} \mathrm{CD} 45^{\text {low }}$ Tregs were shown to develop in a fully mismatched heart allograft model in rat on treatment with CD40Ig (Guillonneau et al. 2007). The therapeutic potential of these regulatory cells has also been highlighted in human studies; in liver and cardiac transplant recipients, expansion of $\mathrm{CD} 8^{+} \mathrm{CD} 28^{-}$Tregs was shown to correlate with low exposure to immu- 
A. Moreau et al.

nosuppressive drugs and a decrease in acute and chronic allograft rejection (Guillonneau et al. 2010).

\section{Memory T Cells}

The presence of memory $\mathrm{T}$ cells able to react with alloantigens was shown in healthy individuals by Lombardi's group in 1990 (Lombardi et al. 1990). Memory T cells showed a faster proliferation, in accordance with observations in vivo during secondary-type immune responses (Akbar et al. 1990). Memory CD8 ${ }^{+}$T cells act as CTLs as they are able to directly kill target cells, mainly via the granzyme/perforin pathway (Barber et al. 2003).

Two distinct subsets of memory $T$ cells have been identified, and are termed central and effector memory cells (Brook et al. 2006). Central and effector memory cells are CD45RO ${ }^{+}$ $\mathrm{CD}_{45 \mathrm{RA}^{-}}$, but differ by their expression of the CD62L/CCR7 markers. Contrary to central memory cells, effector memory cells express more $\beta_{1}$ and $\beta_{2}$ integrins. Moreover, the two subsets differ in their localization because central memory $\mathrm{T}$ cells express intermediate levels of CCR4 and CCR6, whereas effector memory T cells express high levels of CCR1, CCR3, and CCR5. Although central memory T cells require restimulation, this subset is more efficient in their killing function (Sallusto et al. 1999; Barber et al. 2003; Hengel et al. 2003).

In sensitized patients, the presence of memory T cells specific for alloantigens can be caused by prior blood transfusion, pregnancy, or transplant rejection. The presence of allospecific memory $\mathrm{T}$ cells is more difficult to explain in nonsensitized individuals, but may be the result of heterologous immunity or homeostatic proliferation.

Heterologous immunity is defined as the ability of alloreactive memory $\mathrm{T}$ cells specific for a microbial antigen to cross-react with allogeneic MHC molecules through direct allorecognition. This affinity of the $\mathrm{T}$-cell receptor for allogeneic MHC molecules can be higher than that for self-antigens. Heterologous immunity has been shown both in mice and in humans (Smith et al. 2012). Homeostatic proliferation occurs in lymphopenic conditions (such as those caused by certain immunotherapies) and in the absence of an antigenic stimulus. In these conditions, peripheral $\mathrm{T}$ cells rapidly proliferate and acquire a memory phenotype that spontaneously skews toward a Th1 phenotype (Moxham et al. 2008). Certain cytokines, such as IL-7, have been shown to mediate this homeostatic proliferation (Schluns et al. 2000).

Memory T cells generated in the context of viral infections or by homeostatic proliferation may prevent tolerance induction, as shown using well-established rodent models of tolerance (Valujskikh et al. 2002; Zhai et al. 2002; Wu et al. 2004). These results show that memory $\mathrm{T}$ cells can act as barriers to tolerance induction. It is therefore necessary to develop therapies to prevent memory $\mathrm{T}$-cell generation or to eliminate such cells. The effect of immunosuppressive drugs on memory $\mathrm{T}$ cells has started to be studied. So far, it is known that $\mathrm{CD} 4^{+}$memory T cells are resistant to steroids, deoxyspergualin, and sirolimus. In contrast, calcineurin inhibitors tacrolimus and cyclosporine A inhibit their proliferation and in vitro activation (Pearl et al. 2005). Optimal activation of memory $\mathrm{T}$ cells requires costimulatory molecules, which are different from those acting on naïve cells, such as ICOS/ICOSL, OX40/OX40L, and CD27/CD70 (Croft 2003; Wu et al. 2004). Consequently, blockade of the CD27/CD70 pathway prolongs the survival of heart transplant in mice (Yamada et al. 2005). Moreover, IL-7 inhibition blocks allograft rejection mediated by memory $\mathrm{T}$ cells without affecting Tregs (Wang et al. 2006).

\section{Acute Humoral Response}

Although T cells have been considered for many years as playing a predominant role in graft rejection, it is now known that the acute humoral response is the main cause of acute graft loss (Terasaki 2003). In fact, acute humoral rejection accounts for $15 \%$ to $20 \%$ of graft rejection within the first posttransplant year, despite immunosuppressive therapies (Montgomery et al. 2004; Lucas et al. 2011).

The criteria for the diagnosis of acute humoral rejection of kidney transplants were ini- 
tially established by the Banff working group in 2003 (Racusen et al. 2003). At least one of the following criteria must be present for a diagnosis of acute humoral rejection to be made: (1) morphological criteria: presence of neutrophils and/or monocytes/macrophages in peritubular capillaries (PTC) and/or glomeruli, fibrinous arterial necrosis, thrombosis in the glomerular capillaries, arterioles, and/or small arteries and acute tubular damage; (2) immunohistological criteria: C4d deposits in PTC, presence of immunoglobulins, or complement in the fibrinous necrosis of the arteries; (3) serological criteria: presence of circulating antidonor (HLA and non-HLA) antibodies called donor-specific antibodies (DSA).

These criteria were optimized during the 9th Banff conference by including the quantification of C4d deposition (Solez et al. 2008).

Generally, detection of DSA and C4d deposits is associated with an increase in AMR and an inferior graft outcome (Kedainis et al. 2009). Nevertheless, although the presence of C4d deposits in kidney biopsies appears to be a good marker of AMR, during the last Banff meeting it was agreed that AMR can also be diagnosed in the absence of C4d detection (Mengel et al. 2012).

The new objectives of the Banff committee are therefore to characterize AMR by defining: (1) thresholds for microvascular injury and for DSA in AMR, noting that all injuries are specific and all patients with DSA develop AMR, (2) C4d-negative AMR before adding this category to the Banff classification, (3) acute versus chronic AMR, and (4) the significance of intimal arteritis in the absence of necrosis as a histological criteria (Mengel et al. 2012).

\section{B Cells}

The importance of B cells in allograft rejection was shown using B-cell-deficient mice. Several groups, including Brandle and coworkers, as well as Wasowska and colleagues showed that acute allograft rejection was delayed in B-celldeficient mice and could be restored by the administration of hyperimmune sera (Brandle et al. 1998; Wasowska et al. 2001). In humans, the primary role of $\mathrm{B}$ cells as amplifiers of the alloresponse is suggested by the positive reports of B-cell depletion therapy (rituximab) as induction for $\mathrm{ABO}$-incompatible renal transplant recipients (Tyden et al. 2009). However, rituximab-induction therapy was reported to lead to acute cellular rejection in some kidney transplant recipients (Clatworthy et al. 2009). It is therefore thought that B-cell depletion may be quicker at depleting the $\mathrm{B}$ cells that contribute to tolerance than those that promote rejection, thereby temporarily amplifying the alloresponse.

The ability of $\mathrm{B}$ cells to present antigen and to produce antibodies and cytokines means that these cells can take part in allograft rejection by different mechanisms. B cells have the ability to promote T-cell activation/differentiation through costimulatory pathways, or cytokine release (Constant 1999; Zarkhin et al. 2010). B cells have also been shown to promote alloreactive $\mathrm{T}$-cell differentiation into memory $\mathrm{T}$ cells $(\mathrm{Ng}$ et al. 2010). Moreover, a deficiency in B-cell antigen presentation can prolong graft survival (Noorchashm et al. 2006).

More recently, several groups suggested that $\mathrm{B}$ cells might be involved in tolerance. For example, Deng and coworkers showed that antiCD45RB-induced tolerance to heart transplants requires the presence of B cells (Deng et al. 2007). Furthermore, resting B cells expressing donor antigen indefinitely prolonged heterotopic heart transplant survival (Niimi et al. 1998). In rats, long-term allograft tolerance is characterized by an accumulation of B cells expressing genes such as BANK-1, which are associated with tolerance (Le Texier et al. 2011). In addition, anti-CD20-mediated depletion of B cells in mice was shown to accelerate skin graft rejection (DiLillo et al. 2011). A specific population of B cells expressing TIM-1 was identified as having regulatory properties in mouse models of islet transplantation (Ding et al. 2011). Furthermore, a B-cell signature was described in immunosuppressant-free transplant patients who were spontaneously tolerant to their HLA mismatched kidney transplant (Newell et al. 2010; Pallier et al. 2010; Sagoo et al. 2010; Silva et al. 2012). In contrast, spontaneously tolerant liver trans- 
A. Moreau et al.

plant recipients were reported to display an NK cell signature (Martinez-Llordella et al. 2008). These results were confirmed by the analysis of PBMC from kidney and liver transplant patients by the same laboratory, showing that the B-cell signature was only detectable in kidney in immunosuppressant-free kidney transplant patients (Lozano et al. 2011).

\section{Antibodies}

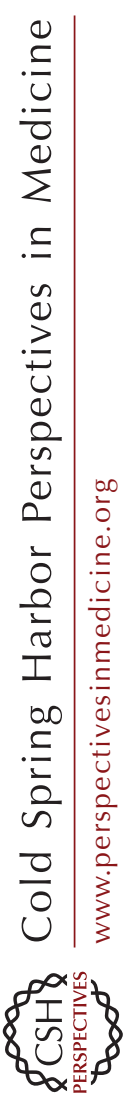

Halloran's group showed the role of alloantibodies in acute humoral rejection in the 1990s. They described a correlation between the prognosis of acute rejection and the production of antidonor antibodies after transplantation (Halloran et al. 1990). In presensitized patients, the presence of DSA at the time of transplantation was identified as a high risk factor for AMR and patients who develop anti-HLA DSA tend to have inferior long-term graft survival compared to those that do not (Lefaucheur et al. 2008, 2010). In support of these results, a recent study by Cooper et al. (2011) also showed that patients who develop de novo DSA after transplantation have an inferior graft outcome.

Alloantibodies that develop against the donor organ can recognize several types of antigens (for review, see Dragun 2008): HLA antigens class I and II (Terasaki and Ozawa 2004; Terasaki and Cai 2005), MICA and MICB antigens (MHC class I-related molecules A and B) (Zou et al. 2007; Li et al. 2010), minor histocompatibility antigens and non-HLA antigens including the angiotensin II type 1 receptor (Dragun et al. 2005), vimentin (Mahesh et al. 2007), myosin, the $\mathrm{ABO}$ blood group antigens (Montgomery et al. 2012), perlecan, type IV and VI collagen, agrin, unknown endothelial antigens (Jackson et al. 2011b), and ICAM-1 (Lawson et al. 2005).

Alloantibodies mainly induce AMR by complement-dependent mechanisms. In fact, the alloantibodies that fix $\mathrm{Clq}$ complement are associated with a worse outcome that does not fix complement (Yabu et al. 2011). A greater risk of acute humoral rejection was clearly shown when C4d deposits were associated with DSA and, more specifically, anti-HLA class I but not anti-HLA class II antibodies (Cosio et al. 2010).
However, in the absence of C4d staining, association of DSA with altered expression of endothelial genes was also found to be a marker of AMR in kidney patients, as the alloantibodies modified the microcirculation (Sis et al. 2009). NK cells and macrophages were also involved in AMR in patients with DSA. On stimulation by alloantibodies, NK cells cause endothelial injury and act as effector cells by killing target cells through the antibody-dependent cellular cytotoxicity pathway (Hidalgo et al. 2010). The role of NK cells is particularly well-defined as NKG2D is a receptor for stress-inducible MICA and, as described previously, this molecule is also highly efficient at stimulating NK cells and certain T-cell subsets (Bauer et al. 1999).

Several desensitizing protocols have been tested to reduce the DSA that cause AMR, including plasmapheresis or IVIg, as well as treatments targeting complement C5 molecules, proteasome, or $\mathrm{CD}^{2} 0^{+}$cells (Gueler et al. 2008; Raedler et al. 2011; Yoo et al. 2012). A combination of these treatments was shown to improve graft survival outcome (Lefaucheur et al. 2009; Montgomery et al. 2011).

\section{CHRONIC REJECTION}

\section{The Origins and Mechanisms of Chronic Rejection}

Since the early 1980s, 1-year graft survival of kidney allografts has increased significantly, reaching more than 90\% (Hariharan et al. 2000; Pascual et al. 2002). Nevertheless, the graft survival in the long term has changed minimally, and the percentage of grafts lost annually after the first year has not changed (Meier-Kriesche et al. 2004). Death with a functioning graft and chronic allograft nephropathy (CAN) are the main causes of graft loss (Halloran et al. 1999; Ojo et al. 2000; Matas et al. 2002; Pascual et al. 2002). The predominance of CAN is $60 \%-70 \%$ in the first year posttransplant (Solez et al. 1998; Nankivell et al. 2003). CAN is an entity that encompasses several different mechanisms that include interstitial fibrosis and tubular atrophy. The natural history of CAN suggests that it can result from both immunological and nonimmu- 
nological phenomena, including calcineurin inhibitors (CNI) toxicity (Nankivell et al. 2003). Chronic dysfunction is also observed in other organ transplants and is often responsible for premature graft loss.

In recent years, significant efforts have been made to describe and classify CAN. In 1990, analyses based in histological studies were performed in the field of kidney transplantation, resulting in the description of a classification system for chronic allograft dysfunction (Classification "Banff 97") (Racusen et al. 1999). This classification is revisited regularly to incorporate the latest scientific data and to try to differentiate lesions associated with chronic rejection (CR) from those observed in response to cardiovascular risk factors or CNI toxicity. The 2005 Banff meeting differentiated the lesions suggestive of chronic allograft rejection (including antibodydependent complement activation lesions) and cell arteritis from the less specific lesions of interstitial fibrosis/tubular atrophy (IF/TA) (Solez et al. 2007, 2008). IF/TA lesions can appear very early after transplantation. At 1 year posttransplant, $>80 \%$ of kidneys have minimal lesions of IF/TA that will deteriorate over time, reaching $>50 \%$ of kidneys with severe lesions at 5 years. The 2011 Banff meeting focused on refining the diagnostic criteria for AMR. As such, C4d-negative AMR was recognized, in which NK cells and endothelial activation were proposed to play a role (Mengel et al. 2012).

\section{The Histological Lesions}

Significant progress has been made in understanding the mechanisms involved in the onset of CR, with the description of arteritis lesions in animal models (Yuan et al. 2002). One predominant observation made during chronic allograft rejection is an increase in the thickness of the intima, resulting in a decrease in vessel caliber with destruction of the internal elastic lamina. This thickening is also because of an accumulation of extracellular matrix and proliferation of myofibroblasts (Pedagogos et al. 1997; Pilmore et al. 2000; Ramirez et al. 2006). An accumulation of macrophages and $\mathrm{CD} 4^{+} \mathrm{T}$ cells has been observed at the periphery of the vessels (Thaunat and Nicoletti 2008; Thaunat et al. 2005, 2006, 2008), whereas $\mathrm{CD} 8^{+} \mathrm{T}$ cells are rarely present. The involvement of T cells in the pathogenesis of CR has been investigated through the study of genetically invalidated mice. In a mouse model of cardiac allotransplantation in which the genes encoding CD40 or CD40L were invalidated, CR was not observed, suggesting that activated $\mathrm{T}$ lymphocytes are required to initiate the phenomenon of CR. Nevertheless, in a rat model of cardiac allotransplantation in which animals were treated with CD40Ig (a molecule interfering with CD40-CD40L interaction), acute rejection was successfully inhibited, but CR occurred in long-term-surviving animals (Guillot et al. 2002). In this same model, the development of CR was prevented by simultaneous blockade of other costimulation pathways, such as RANK and ICOS (Guillonneau et al. 2004, 2005).

In some cases, the graft infiltrate has been found to adopt an organization resembling that of ectopic lymphoid tissues, with the infiltrating B cells capable of producing antidonor antibodies. These lesions of tertiary lymphoid tissue have been identified in kidney transplants, and the process is referred to as lymphoid neogenesis, which is analogous to the ontogenic program triggered during embryo development, the ectopic germinal centers (eGCs) (Thaunat et al. 2010; Cheng et al. 2011). The eGCs participate in the mechanisms of CR maintaining local memory Tand B cells capable of synthesizing cytokines and antibodies. Interestingly, there is minimal overlap between the intragraft humoral response, suggesting a local antibody repertoire. Recently, Thaunat and coworkers showed that a breakdown of B-cell tolerance occurs within the graft during CR (Thaunat et al. 2012). It is thought that the micrograft environment interferes with peripheral deletion of autoreactive immature B cells that, in turn, produce autoantibodies. Recent studies have shown an important role for autoimmunity in the pathogenesis of CR suggesting a cross talk between the alloimmune response and autoimmunity (Sarma et al. 2012). Although all types of Th polarization profiles can lead to terminal CR, Thaunat and coworkers (Deteix et al. 2010) reported on a correlation between shorter graft survival and the 
A. Moreau et al.

presence of Th17 cells that produce IL-17 and IL21 in human transplant patients. The latter group hypothesized that IL-21 promotes intragraft lymphoid neogenesis, which in turn supports the development of a local humoral immune response. Moreover, Burlingham et al. (Burlingham et al. 2007; Keller and Burlingham 2011) showed that the alloimmune response is partly responsible for the development of a Th17 autoimmune response. In this context, Fukami et al. (2009) showed that an anti-IL-17 therapy decreases the production of autoantibodies and the development of CR in a murine model.

\section{The Role of Antibodies and Endothelial Cells}

The involvement of antibodies directed against the graft in chronic rejection has been suggested by several groups showing a negative correlation between the appearance of antidonor antibodies and graft survival (Mao et al. 2007a,b; Sis et al. 2007). The emergence of new techniques to identify antibodies by fluorescence-activated cell sorting, flow cytometry, ELISA (enzymelinked immunosorbent assay), and the most sensitive Luminex technique (flow cytometry with microbeads coated with peptides) now enables a better analysis of the humoral component (Pei et al. 2003). Moreover, recent data showing the existence of deposits during CR suggest the involvement of anti-HLA antibodies with the ability to activate complement (Nickeleit et al. 2002; Regele et al. 2002). However, observations from $\mathrm{ABO}$-incompatible transplants, a context in which complement activation occurs, suggest the existence of adaptation mechanisms, allowing endothelial cells to resist complement activation (Gloor et al. 2006).

However, the effects of antibodies are diverse as described in Figure 2, and not limited to complement activation. Antibodies can also bind to the surface molecules of target cells and recruit other cells by interactions via their constant domain (Rebellato et al. 2006; Won et al. 2006). Recently, Hirohashi et al. described a new role for NK cells in chronic allograft rejection in which donor-specific antibodies interact with NK cells in the absence of complement and trigger transplant vasculopathy (Hirohashi et al. 2012; Li and Baldwin 2012). Last, there is some in vitro data showing that the culture of endothelial cells with antidonor antibodies results in

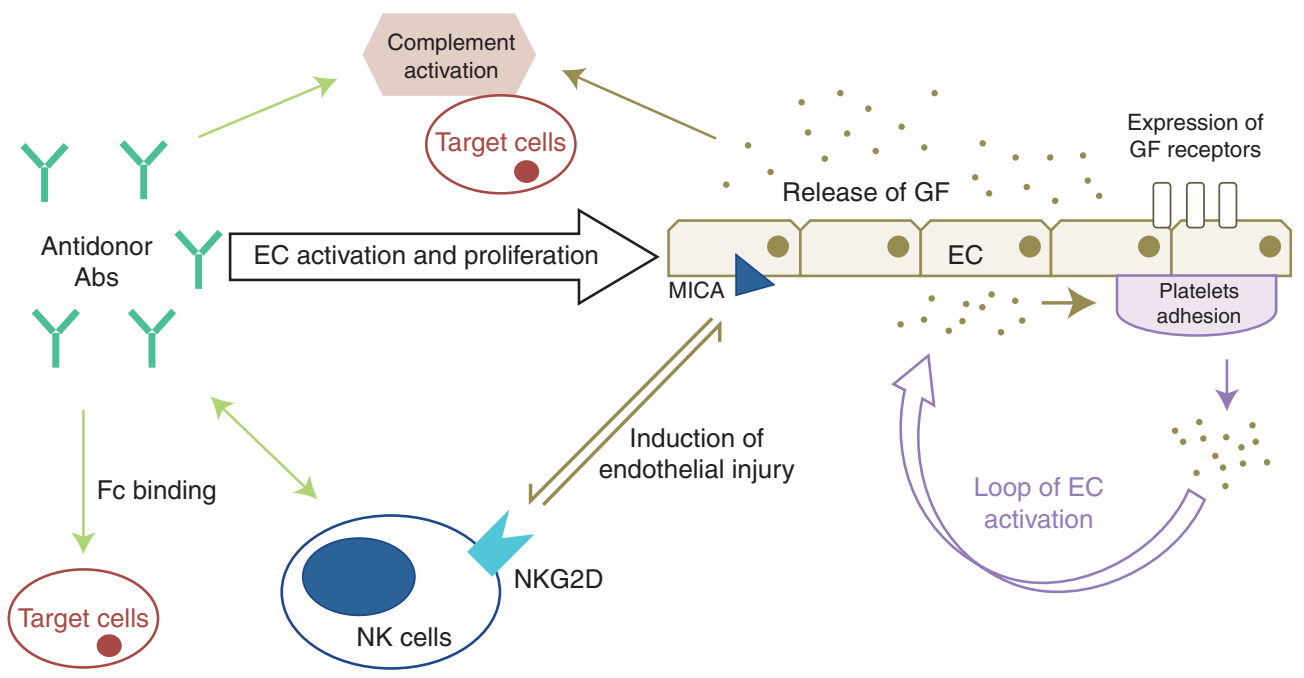

Figure 2. Induction of endothelial cells activation by antidonor antibodies. Antidonor antibodies (Abs) are known to induce chronic allograft rejection by several mechanisms of action involving their constant domain (Fc) or their capacity to induce activation of complement. Antidonor Abs also induce endothelial cell activation. Activated ECs secrete notably growth factors (GF) that induce the recruitment and activation/proliferation of several cells implicated in allograft rejection. 
the activation and proliferation of endothelial cells (Bian and Reed 1999).

This activation step of endothelial cells is associated with the expression of various receptors on their cell surface (PDGF-R, EGF-R, FGF$\mathrm{R})$, as well as the synthesis of numerous growth factors (PDGF, EGF, FGF, VEGF, TGF- $\beta$, etc.) and synthesis of endothelin I (Bian and Reed 2001; Chen et al. 2001; Rossini et al. 2005). The local presence of growth factor is increased by the platelet adhesion that occurs during endothelial-cell activation, resulting in the generation of a local amplification loop with the release of many growth factors such as PDGF and TGF- $\beta$ (MacDermott 1996; Yang et al. 2005). This phase of endothelial-cell activation promotes the stimulation of smooth muscle cells via release of endothelin I, and indirectly via the local synthesis of angiotensin II. It also causes local recruitment of inflammatory cells through the release of chemokines (MCP-1, IP-10), local activation of complement, local coagulation activation, promoting platelet adhesion, and releasing thromboxane A2. Finally, endothelial-cell activation stimulates the differentiation and proliferation of myofibroblast cells that synthesize the extracellular matrix involved in CR (Abbate et al. 2002; Cogan et al. 2002; Dewald et al. 2005; Li et al. 2007; Frangogiannis 2008; Haurani et al. 2008; Kennard et al. 2008; Wynn 2008). Myofibroblastic cells are important constituents of CR as they infiltrate the vessel wall and interstitial space. These cells express different cytoskeletal proteins (vimentin, $\alpha$ smooth muscle actin) as well as the myosin light chain, but do not express markers of lymphoid or epithelial cells (E-cadherin, ZO-1) (Badid et al. 2002). The origin of these cells is diverse. They originate from circulating stem cells capable of differentiating into endothelial cells or myocardiocytes (Direkze et al. 2003; Li et al. 2007). They can also originate from the transdifferentiation of endothelial cells or from renal tubular epithelial cells that transdifferentiate into myofibroblasts (Gressner 1996; Sommer et al. 2005; Hertig et al. 2006). The mechanisms involved remain poorly understood. However, the changes induced by ischemia/reperfusion or during CR appear to promote epithelial- mesenchymal transdifferentiation. TGF- $\beta$ was also shown to be important for the promotion of epithelial-mesenchymal transdifferentiation (Fan et al. 1999; Mezzano et al. 2003; Lindert et al. 2005; Jiang et al. 2006; Meyer-ter-Vehn et al. 2006). Cell differentiation into myofibroblasts and expansion involves various growth factors including TGF- $\beta$, FGF, PDGF, IGF-1, angiotensin II, MCP-1, RANTES, TNF- $\alpha$, IL-15, and connective tissue growth factor.

\section{The Antigenic Targets of Antigens (Antidonor} and Autoantibodies)

One of the independent risk factors for the development of chronic rejection is the presence of anti-HLA class I and especially class II antibodies (Ozawa et al. 2007). More than $80 \%$ of patients with transplant glomerulopathy have anti-HLA antibodies, 85\% being directed against class I or class II antigens (Gloor et al. 2007; Sis et al. 2007; Issa et al. 2008). Less than half of biopsies (40\%) display deposits of C4d, suggesting that mechanisms other than complement activation may be associated with $\mathrm{CR}$ (Solez et al. 2008). Apart from antibodies directed against the major histocompatibility complex HLA, other non-HLA antibodies may also contribute to the structural changes observed during chronic rejection. These include anti-MICA, anti-MICB (MHC class I-related molecules A and B), antiendothelial cells, antivimentin, and other autoantibodies directed against angiotensin II receptor (Dragun et al. 2005, 2008; Hilbrands et al. 2005; Zafar et al. 2006; Panigrahi et al. 2007; Zou et al. 2007; Baid-Agrawal and Frei 2008; Kamoun and Grossman 2008; Sumitran-Holgersson 2008).

\section{Tissue Fibrosis}

During the various immunological and nonimmunological rejection processes, several cell types, particularly endothelial cells, are responsible for the development of an extracellular matrix through the release of growth factors or cytokines such as endothelin I, angiotensin II, TNF, PDGF, TGF, etc. (Coupes et al. 1994; Lu et al. 2002; el-Agroudy et al. 2003; Baczkowska 
A. Moreau et al.

et al. 2005; Summers et al. 2005; Roos-van Groningen et al. 2006). Extracellular matrix accumulation is a lesion of fibrosis. In recent years, it has become apparent that tissue fibrosis is a dynamic equilibrium. Activation of different tissue protease, such as metalloproteinases, or the use of blocking molecule should prevent fibrosis and degrade extracellular matrix. These approaches must be validated in clinical models.

In conclusion, although significant progress has been made in developing immunosuppressive therapies that reduce the occurrence of acute rejection and improve allograft survival at 1 year, little progress has been made regarding graft survival in the longer term. Long-term survival is limited by complex and intricate mechanisms including chronic rejection, immunosuppressive drug toxicity, cardiovascular factors, dyslipidemia, diabetes, and so on. Understanding the mechanisms involved in the onset of chronic rejection should be promoted by approaches such as DNA chips or protein chips to better understand the different stages of development of chronic rejection and the different factors involved. This understanding should help develop new preventive and/or therapeutic approaches in organ transplantation.

\section{REFERENCES}

Abbate M, Zoja C, Rottoli D, Corna D, Tomasoni S, Remuzzi G. 2002. Proximal tubular cells promote fibrogenesis by TGF- $\beta_{1}$-mediated induction of peritubular myofibroblasts. Kidney Int 61: 2066-2077.

Abdi R, Smith RN, Makhlouf L, Najafian N, Luster AD, Auchincloss H Jr, Sayegh MH. 2002. The role of CC chemokine receptor 5 (CCR5) in islet allograft rejection. Diabetes 51: 2489-2495.

Abdi R, Means TK, Ito T, Smith RN, Najafian N, Jurewicz M, Tchipachvili V, Charo I, Auchincloss H Jr, Sayegh MH, et al. 2004. Differential role of CCR2 in islet and heart allograft rejection: Tissue specificity of chemokine/chemokine receptor function in vivo. J Immunol 172: $767-$ 775.

Agostini C, Calabrese F, Rea F, Facco M, Tosoni A, Loy M, Binotto G, Valente M, Trentin L, Semenzato G. 2001. Cxcr3 and its ligand CXCL10 are expressed by inflammatory cells infiltrating lung allografts and mediate chemotaxis of T cells at sites of rejection. Am J Pathol 158: 17031711.

Akashi S, Sho M, Kashizuka H, Hamada K, Ikeda N, Kuzumoto Y, Tsurui Y, Nomi T, Mizuno T, Kanehiro H, et al.
2005. A novel small-molecule compound targeting CCR5 and CXCR3 prevents acute and chronic allograft rejection. Transplantation 80: 378-384.

Akbar AN, Amlot PL, Timms A, Lombardi G, Lechler R, Janossy G. 1990. The development of primed/memory $\mathrm{CD}^{+}$lymphocytes in vitro and in rejecting kidneys after transplantation. Clin Exp Immunol 81: 225-231.

Alferink J, Lieberam I, Reindl W, Behrens A, Weiss S, Huser N, Gerauer K, Ross R, Reske-Kunz AB, Ahmad-Nejad P, et al. 2003. Compartmentalized production of CCL17 in vivo: Strong inducibility in peripheral dendritic cells contrasts selective absence from the spleen. J Exp Med 197: 585-599.

Amano H, Bickerstaff A, Orosz CG, Novick AC, Toma H, Fairchild RL. 2005. Absence of recipient CCR5 promotes early and increased allospecific antibody responses to cardiac allografts. J Immunol 174: 6499-6508.

Anegon I, Cuturi MC, Trinchieri G, Perussia B. 1988. Interaction of Fc receptor (CD16) ligands induces transcription of interleukin 2 receptor (CD25) and lymphokine genes and expression of their products in human natural killer cells. J Exp Med 167: 452-472.

Anglicheau D, Sharma VK, Ding R, Hummel A, Snopkowski C, Dadhania D, Seshan SV, Suthanthiran M. 2009. MicroRNA expression profiles predictive of human renal allograft status. Proc Natl Acad Sci 106: 5330-5335.

Aquino-Dias EC, Joelsons G, da Silva DM, Berdichevski RH, Ribeiro AR, Veronese FJ, Goncalves LF, Manfro RC. 2008. Non-invasive diagnosis of acute rejection in kidney transplants with delayed graft function. Kidney Int 73: 877-884.

Ashton-Chess J, Giral M, Mengel M, Renaudin K, Foucher Y, Gwinner W, Braud C, Dugast E, Quillard T, Thebault P, et al. 2008. Tribbles-1 as a novel biomarker of chronic antibody-mediated rejection. J Am Soc Nephrol 19: 1116-1127.

Ashton-Chess J, Dugast E, Colvin RB, Giral M, Foucher Y, Moreau A, Renaudin K, Braud C, Devys A, Brouard S, et al. 2009. Regulatory, effector, and cytotoxic T cell profiles in long-term kidney transplant patients. J Am Soc Nephrol 20: 1113-1122.

Ashton-Chess J, Mai HL, Jovanovic V, Renaudin K, Foucher Y, Giral M, Moreau A, Dugast E, Mengel M, Racape M, et al. 2010. Immunoproteasome $\beta$ subunit 10 is increased in chronic antibody-mediated rejection. Kidney Int 77: 880-890.

Ayalon O, Hughes EA, Cresswell P, Lee J, O’Donnell L, Pardi $\mathrm{R}$, Bender JR. 1998. Induction of transporter associated with antigen processing by interferon $\gamma$ confers endothelial cell cytoprotection against natural killer-mediated lysis. Proc Natl Acad Sci 95: 2435-2440.

Baczkowska T, Perkowska-Ptasinska A, Sadowska A, Lewandowski Z, Nowacka-Cieciura E, Cieciura T, Pazik J, Lewandowska D, Mroz A, Urbanowicz A, et al. 2005. Serum TGF- $\beta_{1}$ correlates with chronic histopathological lesions in protocol biopsies of kidney allograft recipients. Transplant Proc 37: 773-775.

Badid C, Desmouliere A, Babici D, Hadj-Aissa A, McGregor B, Lefrancois N, Touraine JL, Laville M. 2002. Interstitial expression of $\alpha$-SMA: An early marker of chronic renal allograft dysfunction. Nephrol Dial Transplant 17: 19931998. 
Baid-Agrawal S, Frei UA. 2008. Kidney-transplant rejection and anti-MICA antibodies. N Engl J Med 358: 196.

Barbara JA, Turvey SE, Kingsley CI, Spriewald BM, Hara M, Witzke O, Morris PJ, Wood KJ. 2000. Islet allograft rejection can be mediated by $\mathrm{CD} 4^{+}$, alloantigen experienced, direct pathway T cells of TH1 and TH2 cytokine phenotype. Transplantation 70: 1641-1649.

Barber DL, Wherry EJ, Ahmed R. 2003. Cutting edge: Rapid in vivo killing by memory CD8 T cells. J Immunol 171: $27-31$.

Bauer S, Groh V, Wu J, Steinle A, Phillips JH, Lanier LL, Spies T. 1999. Activation of NK cells and T cells by NKG2D, a receptor for stress-inducible MICA. Science 285: 727-729.

Belperio JA, Ardehali A. 2008. Chemokines and transplant vasculopathy. Circ Res 103: 454-466.

Bestard O, Cruzado JM, Mestre M, Caldes A, Bas J, Carrera M, Torras J, Rama I, Moreso F, Seron D, et al. 2007. Achieving donor-specific hyporesponsiveness is associated with FoxP $3^{+}$regulatory $\mathrm{T}$ cell recruitment in human renal allograft infiltrates. J Immunol 179: 4901-4909.

Bian H, Reed EF. 1999. Alloantibody-mediated class I signal transduction in endothelial cells and smooth muscle cells: Enhancement by IFN- $\gamma$ and TNF- $\alpha$. J Immunol 163: $1010-1018$.

Bian H, Reed EF. 2001. Anti-HLA class I antibodies transduce signals in endothelial cells resulting in FGF receptor translocation, down-regulation of ICAM-1 and cell proliferation. Transplant Proc 33: 311.

Brandle D, Joergensen J, Zenke G, Burki K, Hof RP. 1998. Contribution of donor-specific antibodies to acute allograft rejection: Evidence from B cell-deficient mice. Transplantation 65: 1489-1493.

Braun MY, Desalle F, Le Moine A, Pretolani M, Matthys P, Kiss R, Goldman M. 2000. IL-5 and eosinophils mediate the rejection of fully histoincompatible vascularized cardiac allografts: Regulatory role of alloreactive $\mathrm{CD}^{+} \mathrm{T}$ lymphocytes and IFN- $\gamma$. Eur J Immunol 30: 1290-1296.

Brook MO, Wood JK, Jones ND. 2006. The impact of memory $\mathrm{T}$ cells on rejection and the induction of tolerance. Transplantation 82: 1-9.

Burlingham WJ, Love RB, Jankowska-Gan E, Haynes LD, Xu Q, Bobadilla JL, Meyer KC, Hayney MS, Braun RK, Greenspan DS, et al. 2007. IL-17-dependent cellular immunity to collagen type $\mathrm{V}$ predisposes to obliterative bronchiolitis in human lung transplants. J Clin Invest 117: 3498-3506.

Campbell JJ, Haraldsen G, Pan J, Rottman J, Qin S, Ponath P, Andrew DP, Warnke R, Ruffing N, Kassam N, et al. 1999 The chemokine receptor CCR4 in vascular recognition by cutaneous but not intestinal memory T cells. Nature $\mathbf{4 0 0}$ $776-780$.

Castellano G, Melchiorre R, Loverre A, Ditonno P, Montinaro V, Rossini M, Divella C, Battaglia M, Lucarelli G Annunziata GS, et al. 2010. Therapeutic targeting of classical and lectin pathways of complement protects from ischemia-reperfusion-induced renal damage. Am J Pathol 176: $1648-1659$.

Celli S, Albert ML, Bousso P. 2011. Visualizing the innate and adaptive immune responses underlying allograft rejection by two-photon microscopy. Nat Med 17: 744749.
Chen J, Fabry B, Schiffrin EL, Wang N. 2001. Twisting integrin receptors increases endothelin-1 gene expression in endothelial cells. Am J Physiol Cell Physiol 280: C1475C1484.

Cheng J, Torkamani A, Grover RK, Jones TM, Ruiz DI, Schork NJ, Quigley MM, Hall FW, Salomon DR, Lerner RA. 2011. Ectopic B-cell clusters that infiltrate transplanted human kidneys are clonal. Proc Natl Acad Sci 108: $5560-5565$.

Chong AS, Alegre ML. 2012. The impact of infection and tissue damage in solid-organ transplantation. Nat Rev Immunol 12: 459-471.

Christopher K, Mueller TF, Ma C, Liang Y, Perkins DL. 2002. Analysis of the innate and adaptive phases of allograft rejection by cluster analysis of transcriptional profiles. J Immunol 169: 522-530.

Clatworthy MR, Watson CJ, Plotnek G, Bardsley V, Chaudhry AN, Bradley JA, Smith KG. 2009. B-cell-depleting induction therapy and acute cellular rejection. $N$ Engl J Med 360: 2683-2685.

Cogan JG, Subramanian SV, Polikandriotis JA, Kelm RJ Jr, Strauch AR. 2002. Vascular smooth muscle $\alpha$-actin gene transcription during myofibroblast differentiation requires Sp1/3 protein binding proximal to the MCAT enhancer. J Biol Chem 277: 36433-36442.

Colobran R, Casamitjana N, Roman A, Faner R, Pedrosa E, Arostegui JI, Pujol-Borrell R, Juan M, Palou E. 2009. Copy number variation in the CCL4L gene is associated with susceptibility to acute rejection in lung transplantation. Genes Immun 10: 254-259.

Constant SL. 1999. B lymphocytes as antigen-presenting cells for $\mathrm{CD}^{+} \mathrm{T}$ cell priming in vivo. J Immunol 162: 5695-5703.

Cooper JE, Gralla J, Cagle L, Goldberg R, Chan L, Wiseman AC. 2011. Inferior kidney allograft outcomes in patients with de novo donor-specific antibodies are due to acute rejection episodes. Transplantation 91: 1103-1109.

Cosio FG, Lager DJ, Lorenz EC, Amer H, Gloor JM, Stegall MD. 2010. Significance and implications of capillaritis during acute rejection of kidney allografts. Transplantation 89: 1088-1094

Coudert JD, Coureau C, Guery JC. 2002. Preventing NK cell activation by donor dendritic cells enhances allospecific CD4 $\mathrm{T}$ cell priming and promotes Th type 2 responses to transplantation antigens. J Immunol 169: 2979-2987.

Coupel S, Moreau A, Hamidou M, Horejsi V, Soulillou JP, Charreau B. 2007. Expression and release of soluble HLA$E$ is an immunoregulatory feature of endothelial cell activation. Blood 109: 2806-2814.

Coupes BM, Newstead CG, Short CD, Brenchley PE. 1994. Transforming growth factor $\beta_{1}$ in renal allograft recipients. Transplantation 57: 1727-1731.

Crescioli C, Buonamano A, Scolletta S, Sottili M, Francalanci M, Giomarelli P, Biagioli B, Lisi G, Pradella F, Serio $\mathrm{M}$, et al. 2009. Predictive role of pretransplant serum CXCL10 for cardiac acute rejection. Transplantation 87: 249-255.

Croft M. 2003. Costimulation of T cells by OX40, 4-1BB, and CD27. Cytokine Growth Factor Rev 14: 265-273.

Cuturi MC, Murphy M, Costa-Giomi MP, Weinmann R, Perussia B, Trinchieri G. 1987. Independent regulation 
A. Moreau et al.

of tumor necrosis factor and lymphotoxin production by human peripheral blood lymphocytes. J Exp Med 165: 1581-1594.

Cuturi MC, Anegon I, Sherman F, Loudon R, Clark SC, Perussia B, Trinchieri G. 1989. Production of hematopoietic colony-stimulating factors by human natural killer cells. J Exp Med 169: 569-583.

Deng S, Moore Dj, Huang X, Lian MM, Mohiuddin M, Velededeoglu E, Lee MKT, Sonawane S, Kim J, Wang J, et al. 2007. Cutting edge: Transplant tolerance induced by anti-CD45RB requires B lymphocytes. J Immunol 178: 6028-6032.

Deteix C, Attuil-Audenis V, Duthey A, Patey N, McGregor B, Dubois V, Caligiuri G, Graff-Dubois S, Morelon E, Thaunat O. 2010. Intragraft Th17 infiltrate promotes lymphoid neogenesis and hastens clinical chronic rejection. J Immunol 184: 5344-5351.

Dewald O, Zymek P, Winkelmann K, Koerting A, Ren G Abou-Khamis T, Michael LH, Rollins BJ, Entman ML, Frangogiannis NG. 2005. CCL2/monocyte chemoattractant protein-1 regulates inflammatory responses critical to healing myocardial infarcts. Circ Res 96: 881-889.

Dikow R, Becker LE, Schaier M, Waldherr R, Gross ML, Zeier M. 2010. In renal transplants with delayed graft function chemokines and chemokine receptor expression predict long-term allograft function. Transplantation 90: 771-776.

Dilek N, Poirier N, Usal C, Martinet B, Blancho G, Vanhove B. 2012. Control of transplant tolerance and intragraft regulatory $\mathrm{T}$ cell localization by myeloid-derived suppressor cells and CCL5. J Immunol 188: 4209-4216.

DiLillo DJ, Griffiths R, Seshan SV, Magro CM, Ruiz P, Coffman TM, Tedder TF. 2011. B lymphocytes differentially influence acute and chronic allograft rejection in mice. J Immunol 186: 2643-2654.

Ding R, Li B, Muthukumar T, Dadhania D, Medeiros M, Hartono C, Serur D, Seshan SV, Sharma VK, Kapur S, et al. 2003. CD103 mRNA levels in urinary cells predict acute rejection of renal allografts. Transplantation 75: 1307-1312.

Ding Q, Yeung M, Camirand G, Zeng Q, Akiba H, Yagita H, Chalasani G, Sayegh MH, Najafian N, Rothstein DM. 2011. Regulatory B cells are identified by expression of TIM-1 and can be induced through TIM-1 ligation to promote tolerance in mice. J Clin Invest 121: 3645-3656.

Direkze NC, Forbes SJ, Brittan M, Hunt T, Jeffery R, Preston SL, Poulsom R, Hodivala-Dilke K, Alison MR, Wright NA. 2003. Multiple organ engraftment by bone-marrow-derived myofibroblasts and fibroblasts in bone-marrow-transplanted mice. Stem Cells 21: 514-520.

Dragun D. 2008. Humoral responses directed against nonhuman leukocyte antigens in solid-organ transplantation. Transplantation 86: 1019-1025.

Dragun D, Muller DN, Brasen JH, Fritsche L, NieminenKelha M, Dechend R, Kintscher U, Rudolph B, Hoebeke J, Eckert D, et al. 2005. Angiotensin II type 1-receptor activating antibodies in renal-allograft rejection. $N$ Engl J Med 352: 558-569.

Dragun D, Scornik J, Meier-Kriesche HU. 2008. Kidneytransplant rejection and anti-MICA antibodies. $N$ Engl J Med 358: 196; author reply 196.
Dugre FJ, Gaudreau S, Belles-Isles M, Houde I, Roy R. 2000. Cytokine and cytotoxic molecule gene expression determined in peripheral blood mononuclear cells in the diagnosis of acute renal rejection. Transplantation 70: 1074-1080.

Duluc D, Delneste Y, Tan F, Moles MP, Grimaud L, Lenoir J, Preisser L, Anegon I, Catala L, Ifrah N, et al. 2007. Tumorassociated leukemia inhibitory factor and IL-6 skew monocyte differentiation into tumor-associated macrophage-like cells. Blood 110: 4319-4330.

el-Agroudy AE, Hassan NA, Foda MA, Ismail AM, el-Sawy EA, Mousa O, Ghoneim MA. 2003. Effect of angiotensin II receptor blocker on plasma levels of TGF- $\beta_{1}$ and interstitial fibrosis in hypertensive kidney transplant patients. Am J Nephrol 23: 300-306.

El-Sawy T, Belperio JA, Strieter RM, Remick DG, Fairchild RL. 2005. Inhibition of polymorphonuclear leukocytemediated graft damage synergizes with short-term costimulatory blockade to prevent cardiac allograft rejection. Circulation 112: 320-331.

Epperson DE, Pober JS. 1994. Antigen-presenting function of human endothelial cells. Direct activation of resting CD8 T cells. J Immunol 153: 5402-5412.

Fahim T, Bohmig GA, Exner M, Huttary N, Kerschner H, Kandutsch S, Kerjaschki D, Brambock A, Nagy-Bojarszky K, Regele H. 2007. The cellular lesion of humoral rejection: Predominant recruitment of monocytes to peritubular and glomerular capillaries. Am J Transplant 7: 385393.

Fahmy NM, Yamani MH, Starling RC, Ratliff NB, Young JB, McCarthy PM, Feng J, Novick AC, Fairchild RL. 2003. Chemokine and receptor-gene expression during early and late acute rejection episodes in human cardiac allografts. Transplantation 75: 2044-2047.

Fan JM, Ng YY, Hill PA, Nikolic-Paterson DJ, Mu W, Atkins RC, Lan HY. 1999. Transforming growth factor- $\beta$ regulates tubular epithelial-myofibroblast transdifferentiation in vitro. Kidney Int 56: 1455-1467.

Farid WR, Pan Q, van der Meer AJ, de Ruiter PE, Ramakrishnaiah V, de Jonge J, Kwekkeboom J, Janssen HL, Metselaar HJ, Tilanus HW, et al. 2012. Hepatocytederived microRNAs as serum biomarkers of hepatic injury and rejection after liver transplantation. Liver Transpl 18: 290-297.

Fong AM, Robinson LA, Steeber DA, Tedder TF, Yoshie O, Imai T, Patel DD. 1998. Fractalkine and CX3CR1 mediate a novel mechanism of leukocyte capture, firm adhesion, and activation under physiologic flow. J Exp Med 188: 1413-1419.

Foussat A, Coulomb-L'Hermine A, Gosling J, Krzysiek R, Durand-Gasselin I, Schall T, Balian A, Richard Y, Galanaud P, Emilie D. 2000. Fractalkine receptor expression by T lymphocyte subpopulations and in vivo production of fractalkine in human. Eur J Immunol 30: 87-97.

Frangogiannis NG. 2008. The immune system and cardiac repair. Pharmacol Res 58: 88-111.

Friedman BH, Wolf JH, Wang L, Putt ME, Shaked A, Christie JD, Hancock WW, Olthoff KM. 2012. Serum cytokine profiles associated with early allograft dysfunction in patients undergoing liver transplantation. Liver Transpl 18: $166-176$. 
Fukami N, Ramachandran S, Saini D, Walter M, Chapman W, Patterson GA, Mohanakumar T. 2009. Antibodies to MHC class I induce autoimmunity: Role in the pathogenesis of chronic rejection. J Immunol 182: 309-318.

Gao W, Faia KL, Csizmadia V, Smiley ST, Soler D, King JA, Danoff TM, Hancock WW. 2001. Beneficial effects of targeting CCR5 in allograft recipients. Transplantation 72: 1199-1205.

Garrod KR, Liu FC, Forrest LE, Parker I, Kang SM, Cahalan MD. 2010. NK cell patrolling and elimination of donorderived dendritic cells favor indirect alloreactivity. J Immunol 184: 2329-2336.

Gelman AE, Okazaki M, Sugimoto S, Li W, Kornfeld CG, Lai J, Richardson SB, Kreisel FH, Huang HJ, Tietjens JR, et al. 2010. CCR2 regulates monocyte recruitment as well as CD4 T1 allorecognition after lung transplantation. Am J Transplant 10: 1189-1199.

Gloor JM, Cosio FG, Rea DJ, Wadei HM, Winters JL, Moore SB, DeGoey SR, Lager DJ, Grande JP, Stegall MD. 2006. Histologic findings one year after positive crossmatch or $\mathrm{ABO}$ blood group incompatible living donor kidney transplantation. Am J Transplant 6: 1841-1847.

Gloor JM, Sethi S, Stegall MD, Park WD, Moore SB, DeGoey S, Griffin MD, Larson TS, Cosio FG. 2007. Transplant glomerulopathy: Subclinical incidence and association with alloantibody. Am J Transplant 7: 2124-2132.

Gregson AL, Hoji A, Saggar R, Ross DJ, Kubak BM, Jamieson BD, Weigt SS, Lynch JP III, Ardehali A, Belperio JA, et al. 2008. Bronchoalveolar immunologic profile of acute human lung transplant allograft rejection. Transplantation 85: 1056-1059.

Gressner AM. 1996. Transdifferentiation of hepatic stellate cells (Ito cells) to myofibroblasts: A key event in hepatic fibrogenesis. Kidney Int Suppl 54: S39-S45.

Griffin GK, Newton G, Tarrio ML, Bu DX, Maganto-Garcia E, Azcutia V, Alcaide P, Grabie N, Luscinskas FW, Croce $\mathrm{KJ}$, et al. 2012. IL-17 and TNF- $\alpha$ sustain neutrophil recruitment during inflammation through synergistic effects on endothelial activation. J Immunol 188: 62876299.

Gueler F, Rong S, Gwinner W, Mengel M, Brocker V, Schon S, Greten TF, Hawlisch H, Polakowski T, Schnatbaum K, et al. 2008. Complement 5 a receptor inhibition improves renal allograft survival. J Am Soc Nephrol 19: 2302-2312.

Guillonneau C, Louvet C, Renaudin K, Heslan JM, Heslan M, Tesson L, Vignes C, Guillot C, Choi Y, Turka LA, et al. 2004. The role of TNF-related activation-induced cytokine-receptor activating NF- $\mathrm{\kappa B}$ interaction in acute allograft rejection and CD40L-independent chronic allograft rejection. J Immunol 172:1619-1629.

Guillonneau C, Aubry V, Renaudin K, Seveno C, Usal C, Tezuka K, Anegon I. 2005. Inhibition of chronic rejection and development of tolerogenic $\mathrm{T}$ cells after ICOS-ICOSL and CD40-CD40L co-stimulation blockade. Transplantation 80: 546-554.

Guillonneau C, Hill M, Hubert FX, Chiffoleau E, Herve C, Li XL, Heslan M, Usal C, Tesson L, Menoret S, et al. 2007. CD40Ig treatment results in allograft acceptance mediated by CD8CD45RC T cells, IFN- $\gamma$, and indoleamine 2,3dioxygenase. J Clin Invest 117: 1096-1106.
Guillonneau C, Picarda E, Anegon I. 2010. CD8 ${ }^{+}$regulatory $\mathrm{T}$ cells in solid organ transplantation. Curr Opin Organ Transplant (to be published).

Guillot C, Guillonneau C, Mathieu P, Gerdes CA, Menoret S, Braudeau C, Tesson L, Renaudin K, Castro MG, Lowenstein PR, et al. 2002. Prolonged blockade of CD40-CD40 ligand interactions by gene transfer of CD40Ig results in long-term heart allograft survival and donor-specific hyporesponsiveness, but does not prevent chronic rejection. J Immunol 168: 1600-1609.

Halloran PF, Wadgymar A, Ritchie S, Falk J, Solez K, Srinivasa NS. 1990. The significance of the anti-class I antibody response. I: Clinical and pathologic features of anticlass I-mediated rejection. Transplantation 49: 85-91.

Halloran PF, Melk A, Barth C. 1999. Rethinking chronic allograft nephropathy: The concept of accelerated senescence. J Am Soc Nephrol 10: 167-181.

Hancock WW, Thomson NM, Atkins RC. 1983. Composition of interstitial cellular infiltrate identified by monoclonal antibodies in renal biopsies of rejecting human renal allografts. Transplantation 35: 458-463.

Hancock WW, Lu B, Gao W, Csizmadia V, Faia K, King JA, Smiley ST, Ling M, Gerard NP, Gerard C. 2000. Requirement of the chemokine receptor CXCR3 for acute allograft rejection. J Exp Med 192: 1515-1520.

Hariharan S, Johnson CP, Bresnahan BA, Taranto SE, McIntosh MJ, Stablein D. 2000. Improved graft survival after renal transplantation in the United States, 1988 to 1996. N Engl J Med 342: 605-612.

Haurani MJ, Cifuentes ME, Shepard AD, Pagano PJ. 2008. Nox4 oxidase overexpression specifically decreases endogenous Nox4 mRNA and inhibits angiotensin II-induced adventitial myofibroblast migration. Hypertension 52: $143-149$.

He H, Stone JR, Perkins DL. 2002. Analysis of robust innate immune response after transplantation in the absence of adaptive immunity. Transplantation 73: 853-861.

He H, Stone JR, Perkins DL, Perkins. 2003. Analysis of differential immune responses induced by innate and adaptive immunity following transplantation. Immunology 109: 185-196.

Heeger PS, Greenspan NS, Kuhlenschmidt S, Dejelo C, Hricik DE, Schulak JA, Tary-Lehmann M. 1999. Pretransplant frequency of donor-specific, IFN- $\gamma$-producing lymphocytes is a manifestation of immunologic memory and correlates with the risk of posttransplant rejection episodes. J Immunol 163: 2267-2275.

Hengel RL, Thaker V, Pavlick MV, Metcalf JA, Dennis G Jr, Yang J, Lempicki RA, Sereti I, Lane HC. 2003. Cutting edge: L-selectin (CD62L) expression distinguishes small resting memory $\mathrm{CD} 4^{+} \mathrm{T}$ cells that preferentially respond to recall antigen. J Immunol 170: 28-32.

Herrera OB, Golshayan D, Tibbott R, Salcido Ochoa F, James MJ, Marelli-Berg FM, Lechler RI. 2004. A novel pathway of alloantigen presentation by dendritic cells. J Immunol 173: 4828-4837.

Hertig A, Verine J, Mougenot B, Jouanneau C, Ouali N, Sebe P, Glotz D, Ancel PY, Rondeau E, Xu-Dubois YC. 2006. Risk factors for early epithelial to mesenchymal transition in renal grafts. Am J Transplant 6: 2937-2946.

Hidalgo LG, Sis B, Sellares J, Campbell PM, Mengel M, Einecke G, Chang J, Halloran PF. 2010. NK cell transcripts 
A. Moreau et al.

and NK cells in kidney biopsies from patients with donor-specific antibodies: Evidence for NK cell involvement in antibody-mediated rejection. Am J Transplant 10: $1812-1822$.

Hilbrands L, Hoitsma A, Wetzels J. 2005. Angiotensin II type 1-receptor activating antibodies in renal-allograft rejection. N Engl J Med 352: 2027-2028.

Hirohashi T, Chase CM, Della Pelle P, Sebastian D, Alessandrini A, Madsen JC, Russell PS, Colvin RB. 2012. A novel pathway of chronic allograft rejection mediated by NK cells and alloantibody. Am J Transplant 12: 313-321.

Ho J, Rush DN, Gibson IW, Karpinski M, Storsley L, Bestland J, Stefura W, HayGlass KT, Nickerson PW. 2010. Early urinary CCL2 is associated with the later development of interstitial fibrosis and tubular atrophy in renal allografts. Transplantation 90: 394-400.

Hoerning A, Koss K, Datta D, Boneschansker L, Jones CN Wong IY, Irimia D, Calzadilla K, Benitez F, Hoyer PF, et al. 2011. Subsets of human $\mathrm{CD}^{+}{ }^{+}$regulatory T cells express the peripheral homing receptor CXCR3. Eur J Immunol 41: 2291-2302.

Hoffmann U, Segerer S, Rummele P, Kruger B, Pietrzyk M, Hofstadter F, Banas B, Kramer BK. 2006. Expression of the chemokine receptor CXCR3 in human renal allografts-A prospective study. Nephrol Dial Transplant 21: $1373-1381$.

Hoffmann U, Bergler T, Segerer S, Rummele P, Kruger B, Banas MC, Reinhold S, Banas B, Kramer BK. 2010. Impact of chemokine receptor CX3CR1 in human renal allograft rejection. Transpl Immunol 23: 204-208.

Hopken UE, Droese J, Li JP, Joergensen J, Breitfeld D, Zerwes HG, Lipp M. 2004. The chemokine receptor CCR7 controls lymph node-dependent cytotoxic $\mathrm{T}$ cell priming in alloimmune responses. Eur J Immunol 34: 461-470.

Horne PH, Zimmerer JM, Fisher MG, Lunsford KE, Nadasdy G, Nadasdy T, van Rooijen N, Bumgardner GL. 2008. Critical role of effector macrophages in mediating CD4-dependent alloimmune injury of transplanted liver parenchymal cells. J Immunol 181: 1224-1231.

Hu H, Kwun J, Aizenstein BD, Knechtle SJ. 2009. Noninvasive detection of acute and chronic injuries in human renal transplant by elevation of multiple cytokines/chemokines in urine. Transplantation 87: 1814-1820.

Huser N, Tertilt C, Gerauer K, Maier S, Traeger T, Assfalg V, Reiter R, Heidecke CD, Pfeffer K. 2005. CCR4-deficient mice show prolonged graft survival in a chronic cardiac transplant rejection model. Eur J Immunol 35: 128-138.

Imai T, Hieshima K, Haskell C, Baba M, Nagira M, Nishimura M, Kakizaki M, Takagi S, Nomiyama H, Schall TJ, et al. 1997. Identification and molecular characterization of fractalkine receptor CX3CR1, which mediates both leukocyte migration and adhesion. Cell 91: 521-530.

Issa N, Cosio FG, Gloor JM, Sethi S, Dean PG, Moore SB, DeGoey S, Stegall MD. 2008. Transplant glomerulopathy: Risk and prognosis related to anti-human leukocyte antigen class II antibody levels. Transplantation 86: 681685.

Ito A, Shimura H, Nitahara A, Tomiyama K, Ito M, Kanekura T, Okumura K, Yagita H, Kawai K. 2008. NK cells contribute to the skin graft rejection promoted by $\mathrm{CD} 4^{+}$ $\mathrm{T}$ cells activated through the indirect allorecognition pathway. Int Immunol 20: 1343-1349.
Iwasaki A, Medzhitov R. 2010. Regulation of adaptive immunity by the innate immune system. Science 327 : 291295.

Jackson JA, Kim EJ, Begley B, Cheeseman J, Harden T, Perez SD, Thomas S, Warshaw B, Kirk AD. 2011a. Urinary chemokines CXCL9 and CXCL10 are noninvasive markers of renal allograft rejection and BK viral infection. Am J Transplant 11: 2228-2234.

Jackson AM, Lucas DP, Melancon JK, Desai NM. 2011b. Clinical relevance and IgG subclass determination of non-HLA antibodies identified using endothelial cell precursors isolated from donor blood. Transplantation 92: $54-60$.

Ji J, Yu YY, Chen H, Deng XX, Shen BY, Zhou GW, Peng CW, Li HW. 2004. Perforin and granzyme B expression in liver allograft rejection. Zhonghua Gan Zang Bing Za Zhi 12: 325-327.

Jiang YL, Dai AG, Li QF, Hu RC. 2006. Transforming growth factor- $\beta 1$ induces transdifferentiation of fibroblasts into myofibroblasts in hypoxic pulmonary vascular remodeling. Acta Biochim Biophys Sin (Shanghai) 38: 29-36.

Jose MD, Le Meur Y, Atkins RC, Chadban SJ. 2003. Blockade of macrophage colony-stimulating factor reduces macrophage proliferation and accumulation in renal allograft rejection. Am J Transplant 3: 294-300.

Jungraithmayr W, Inci I, Bain M, Hillinger S, Korom S, Weder W. 2010. Distribution of macrophages and T cells in syngrafts and allografts after experimental rat lung transplantation. Immunobiology 215: 206-214.

Kakuta Y, Okumi M, Miyagawa S, Tsutahara K, Abe T, Yazawa K, Matsunami K, Otsuka H, Takahara S, Nonomura N. 2012. Blocking of CCR5 and CXCR3 suppresses the infiltration of macrophages in acute renal allograft rejection. Transplantation 93: 24-31.

Kamoun M, Grossman RA. 2008. Kidney-transplant rejection and anti-MICA antibodies. N Engl J Med 358: 195.

Kedainis RL, Koch MJ, Brennan DC, Liapis H. 2009. Focal $\mathrm{C}_{4} \mathrm{~d}^{+}$in renal allografts is associated with the presence of donor-specific antibodies and decreased allograft survival. Am J Transplant 9: 812-819.

Keller MR, Burlingham WJ. 2011. Loss of tolerance to self after transplant. Semin Immunopathol 33: 105-110.

Kennard S, Liu H, Lilly B. 2008. Transforming growth factor- $\beta$ (TGF-1) down-regulates Notch3 in fibroblasts to promote smooth muscle gene expression. J Biol Chem 283: $1324-1333$

Kim J, Chang CK, Hayden T, Liu FC, Benjamin J, Hamerman JA, Lanier LL, Kang SM. 2007. The activating immunoreceptor NKG2D and its ligands are involved in allograft transplant rejection. J Immunol 179: 64166420 .

Kingsley CI, Karim M, Bushell AR, Wood KJ. 2002. CD25 $\mathrm{CD}^{+}$regulatory $\mathrm{T}$ cells prevent graft rejection: CTLA4- and IL-10-dependent immunoregulation of alloresponses. J Immunol 168: 1080-1086.

Kirk AD, Morrell CN, Baldwin WM III. 2009. Platelets influence vascularized organ transplants from start to finish. Am J Transplant 9: 14-22.

Kozakowski N, Bohmig GA, Exner M, Soleiman A, Huttary N, Nagy-Bojarszky K, Ecker RC, Kikic Z, Regele H. 2009. Monocytes/macrophages in kidney allograft intimal ar- 
teritis: No association with markers of humoral rejection or with inferior outcome. Nephrol Dial Transplant 24: 1979-1986.

Krams SM, Villanueva JC, Quinn MB, Martinez OM. 1995. Expression of the cytotoxic T cell mediator granzyme B during liver allograft rejection. Transpl Immunol 3: 162166.

Kroemer A, Xiao X, Degauque N, Edtinger K, Wei H, Demirci G, Li XC. 2008. The innate NK cells, allograft rejection, and a key role for IL-15. J Immunol 180: 7818-7826.

Kwun J, Hazinedaroglu SM, Schadde E, Kayaoglu HA, Fechner J, Hu HZ, Roenneburg D, Torrealba J, Shiao L, Hong $\mathrm{X}$, et al. 2008. Unaltered graft survival and intragraft lymphocytes infiltration in the cardiac allograft of $\mathrm{CXCR}^{-7-}$ mouse recipients. Am J Transplant 8: $1593-$ 1603.

Laffont S, Seillet C, Ortaldo J, Coudert JD, Guery JC. 2008. Natural killer cells recruited into lymph nodes inhibit alloreactive T-cell activation through perforin-mediated killing of donor allogeneic dendritic cells. Blood 112: 661-671.

Land WG. 2005. The role of postischemic reperfusion injury and other nonantigen-dependent inflammatory pathways in transplantation. Transplantation 79: 505-514

LaRosa DF, Rahman AH, Turka LA. 2007. The innate immune system in allograft rejection and tolerance. J Immunol 178:7503-7509.

Lawson C, Holder AL, Stanford RE, Smith J, Rose ML. 2005. Anti-intercellular adhesion molecule- 1 antibodies in sera of heart transplant recipients: A role in endothelial cell activation. Transplantation 80: 264-271.

Lazzeri E, Rotondi M, Mazzinghi B, Lasagni L, Buonamano A, Rosati A, Pradella F, Fossombroni V, La Villa G, Gacci M, et al. 2005. High CXCL10 expression in rejected kidneys and predictive role of pretransplant serum CXCL10 for acute rejection and chronic allograft nephropathy. Transplantation 79: 1215-1220.

Lee I, Wang L, Wells AD, Ye Q, Han R, Dorf ME, Kuziel WA, Rollins BJ, Chen L, Hancock WW. 2003. Blocking the monocyte chemoattractant protein-1/CCR2 chemokine pathway induces permanent survival of islet allografts through a programmed death-1 ligand-1-dependent mechanism. J Immunol 171: 6929-6935.

Lee I, Wang L, Wells AD, Dorf ME, Ozkaynak E, Hancock W. 2005. Recruitment of FoxP3 ${ }^{+}$Tregulatory cells mediating allograft tolerance depends on the CCR4 chemokine receptor. J Exp Med 201: 1037-1044.

Lefaucheur C, Suberbielle-Boissel C, Hill GS, Nochy D, Andrade J, Antoine C, Gautreau C, Charron D, Glotz D. 2008. Clinical relevance of preformed HLA donor-specific antibodies in kidney transplantation. Am J Transplant 8: 324-331.

Lefaucheur C, Nochy D, Andrade J, Verine J, Gautreau C, Charron D, Hill GS, Glotz D, Suberbielle-Boissel C. 2009. Comparison of combination plasmapheresis/IVIg/antiCD20 versus high-dose IVIg in the treatment of antibody-mediated rejection. Am J Transplant 9: 1099-1107.

Lefaucheur C, Loupy A, Hill GS, Andrade J, Nochy D, Antoine C, Gautreau C, Charron D, Glotz D, SuberbielleBoissel C. 2010. Preexisting donor-specific HLA antibodies predict outcome in kidney transplantation. J Am Soc Nephrol 21: 1398-1406.
Le Texier L, Thebault P, Lavault A, Usal C, Merieau E, Quillard T, Charreau B, Soulillou JP, Cuturi MC, Brouard S, et al. 2011. Long-term allograft tolerance is characterized by the accumulation of $\mathrm{B}$ cells exhibiting an inhibited profile. Am J Transplant 11: 429-438.

Li XC, Baldwin WM III. 2012. NK cells: New partners in antibody-triggered chronic rejection. Am J Transplant 12: 275-276.

Li B, Hartono C, Ding R, Sharma VK, Ramaswamy R, Qian B, Serur D, Mouradian J, Schwartz JE, Suthanthiran M. 2001. Noninvasive diagnosis of renal-allograft rejection by measurement of messenger RNA for perforin and granzyme B in urine. N Engl J Med 344: 947-954.

Li Y, Koshiba T, Yoshizawa A, Yonekawa Y, Masuda K, Ito A, Ueda M, Mori T, Kawamoto H, Tanaka Y, et al. 2004. Analyses of peripheral blood mononuclear cells in operational tolerance after pediatric living donor liver transplantation. Am J Transplant 4: 2118-2125.

Li J, Deane JA, Campanale NV, Bertram JF, Ricardo SD 2007. The contribution of bone marrow-derived cells to the development of renal interstitial fibrosis. Stem Cells 25: 697-706.

Li L, Chen A, Chaudhuri A, Kambham N, Sigdel T, Chen R, Sarwal MM. 2010. Compartmental localization and clinical relevance of MICA antibodies after renal transplantation. Transplantation 89: 312-319.

Li J, Chen G, Ye P, Wang S, Zhang K, Chen W, Stepkowski SM, Li J, Zhong S, Xia J. 2011. CCR5 blockade in combination with cyclosporine increased cardiac graft survival and generated alternatively activated macrophages in primates. J Immunol 186: 3753-3761.

Li H, Xie HY, Zhou L, Feng XW, Wang WL, Liang TB, Zhang M, Zheng SS. 2012. Copy number variation in CCL3L1 gene is associated with susceptibility to acute rejection in patients after liver transplantation. Clin Transplant 26: 314-321.

Lin D, Lavender H, Soilleux EJ, O'Callaghan CA. 2012. NF$\kappa \mathrm{B}$ regulates MICA gene transcription in endothelial cell through a genetically inhibitable control site. J Biol Chem 287: 4299-4310.

Lindert S, Wickert L, Sawitza I, Wiercinska E, Gressner AM, Dooley S, Breitkopf K. 2005. Transdifferentiation-dependent expression of $\alpha$-SMA in hepatic stellate cells does not involve TGF- $\beta$ pathways leading to coinduction of collagen type I and thrombospondin-2. Matrix Biol 24: 198-207.

Liu X, Mishra P, Yu S, Beckmann J, Wendland M, Kocks J, Seth S, Hoffmann K, Hoffmann M, Kremmer E, et al. 2011. Tolerance induction towards cardiac allografts under costimulation blockade is impaired in CCR7-deficient animals but can be restored by adoptive transfer of syngeneic plasmacytoid dendritic cells. Eur J Immunol 41: 611-623.

Lo DJ, Weaver TA, Kleiner DE, Mannon RB, Jacobson LM, Becker BN, Swanson SJ, Hale DA, Kirk AD. 2011. Chemokines and their receptors in human renal allotransplantation. Transplantation 91: 70-77.

Lombardi G, Sidhu S, Daly M, Batchelor JR, Makgoba W, Lechler RI. 1990. Are primary alloresponses truly primary? Int Immunol 2: 9-13.

Lorenzen JM, Volkmann I, Fiedler J, Schmidt M, Scheffner I, Haller H, Gwinner W, Thum T. 2011. Urinary miR-210 as 
A. Moreau et al.

a mediator of acute T-cell mediated rejection in renal allograft recipients. Am J Transplant 11: 2221-2227.

Lozano JJ, Pallier A, Martinez-Llordella M, Danger R, Lopez M, Giral M, Londono MC, Rimola A, Soulillou JP, Brouard S, et al. 2011. Comparison of transcriptional and blood cell-phenotypic markers between operationally tolerant liver and kidney recipients. Am J Transplant 11: 1916-1926.

Lu KC, Jaramillo A, Lecha RL, Schuessler RB, Aloush A, Trulock EP, Mendeloff EN, Huddleston CB, Alexander Patterson G, Mohanakumar T. 2002. Interleukin-6 and interferon- $\gamma$ gene polymorphisms in the development of bronchiolitis obliterans syndrome after lung transplantation. Transplantation 74: 1297-1302.

Lucas JG, Co JP, Nwaogwugwu UT, Dosani I, Sureshkumar KK. 2011. Antibody-mediated rejection in kidney transplantation: An update. Expert Opin Pharmacother 12: 579-592.

Lumeng CN, Bodzin JL, Saltiel AR. 2007. Obesity induces a phenotypic switch in adipose tissue macrophage polarization. J Clin Invest 117: 175-184.

MacDermott RP. 1996. Alterations of the mucosal immune system in inflammatory bowel disease. J Gastroenterol 31: 907-916.

Madsen CB, Norgaard A, Iversen M, Ryder LP. 2010. Elevated mRNA levels of CTLA-4, FoxP3, and granzyme B in BAL, but not in blood, during acute rejection of lung allografts. Transpl Immunol 24: 26-32.

Magil AB. 2005. Infiltrating cell types in transplant glomerulitis: Relationship to peritubular capillary C4d deposition. Am J Kidney Dis 45: 1084-1089.

Magil AB, Tinckam KJ. 2006. Focal peritubular capillary C4d deposition in acute rejection. Nephrol Dial Transplant 21: 1382-1388.

Mahesh B, Leong HS, McCormack A, Sarathchandra P, Holder A, Rose ML. 2007. Autoantibodies to vimentin cause accelerated rejection of cardiac allografts. Am J Pathol 170: $1415-1427$.

Maier S, Tertilt C, Chambron N, Gerauer K, Huser N, Heidecke CD, Pfeffer K. 2001. Inhibition of natural killer cells results in acceptance of cardiac allografts in $\mathrm{CD} 28^{-/-}$ mice. Nat Med 7: 557-562.

Manes TD, Pober JS. 2008. Antigen presentation by human microvascular endothelial cells triggers ICAM-1-dependent transendothelial protrusion by, and fractalkine-dependent transendothelial migration of, effector memory $\mathrm{CD}^{+}{ }^{+} \mathrm{T}$ cells. J Immunol 180: 8386-8392.

Manes TD, Shiao SL, Dengler TJ, Pober JS. 2007. TCR signaling antagonizes rapid IP-10-mediated transendothelial migration of effector memory $\mathrm{CD}^{+} \mathrm{T}$ cells. J Immunol 178: 3237-3243.

Mantovani A, Sica A, Sozzani S, Allavena P, Vecchi A, Locati M. 2004. The chemokine system in diverse forms of macrophage activation and polarization. Trends Immunol 25: 677-686.

Mao Q, Terasaki PI, Cai J, Briley K, Catrou P, Haisch C, Rebellato L. 2007a. Extremely high association between appearance of HLA antibodies and failure of kidney grafts in a five-year longitudinal study. Am J Transplant 7: 864871.
Mao Q, Terasaki PI, Cai J, El-Awar N, Rebellato L. 2007b. Analysis of HLA class I specific antibodies in patients with failed allografts. Transplantation 83: 54-61.

Mao Y, Wang M, Zhou Q, Jin J, Wang Y, Peng W, Wu J, Shou Z, Chen J. 2011. CXCL10 and CXCL13 Expression were highly up-regulated in peripheral blood mononuclear cells in acute rejection and poor response to anti-rejection therapy. J Clin Immunol 31: 414-418.

Martinez-Dolz L, Almenar L, Reganon E, Vila V, SanchezSoriano R, Martinez-Sales V, Moro J, Aguero J, SanchezLazaro I, Salvador A. 2009. What is the best biomarker for diagnosis of rejection in heart transplantation? Clin Transplant 23: 672-680.

Martinez-Llordella M, Puig-Pey I, Orlando G, Ramoni M, Tisone G, Rimola A, Lerut J, Latinne D, Margarit C, Bilbao I, et al. 2007. Multiparameter immune profiling of operational tolerance in liver transplantation. Am J Transplant 7: 309-319.

Martinez-Llordella M, Lozano JJ, Puig-Pey I, Orlando G, Tisone G, Lerut J, Benitez C, Pons JA, Parrilla P, Ramirez P, et al. 2008. Using transcriptional profiling to develop a diagnostic test of operational tolerance in liver transplant recipients. J Clin Invest 118: 2845-2857.

Matas AJ, Humar A, Gillingham KJ, Payne WD, Gruessner RW, Kandaswamy R, Dunn DL, Najarian JS, Sutherland DE. 2002. Five preventable causes of kidney graft loss in the 1990s: A single-center analysis. Kidney Int 62: 704714.

Matz M, Beyer J, Wunsch D, Mashreghi MF, Seiler M, Pratschke J, Babel N, Volk HD, Reinke P, Kotsch K. 2006. Early post-transplant urinary IP-10 expression after kidney transplantation is predictive of short- and long-term graft function. Kidney Int 69: 1683-1690.

McDouall RM, Batten P, McCormack A, Yacoub MH, Rose ML. 1997. MHC class II expression on human heart microvascular endothelial cells: Exquisite sensitivity to interferon- $\gamma$ and natural killer cells. Transplantation 64: $1175-1180$.

McNerney ME, Lee KM, Zhou P, Molinero L, Mashayekhi M, Guzior D, Sattar H, Kuppireddi S, Wang CR, Kumar V, Alegre ML. 2006. Role of natural killer cell subsets in cardiac allograft rejection. Am J Transplant 6: 505-513.

Meier-Kriesche HU, Schold JD, Kaplan B. 2004. Long-term renal allograft survival: Have we made significant progress or is it time to rethink our analytic and therapeutic strategies? Am J Transplant 4: 1289-1295.

Mengel M, Sis B, Haas M, Colvin RB, Halloran PF, Racusen LC, Solez K, Cendales L, Demetris AJ, Drachenberg CB, et al. 2012. Banff 2011 meeting report: New concepts in antibody-mediated rejection. Am J Transplant 12: $563-$ 570 .

Meyer-ter-Vehn T, Sieprath S, Katzenberger B, Gebhardt S, Grehn F, Schlunck G. 2006. Contractility as a prerequisite for TGF- $\beta$-induced myofibroblast transdifferentiation in human tenon fibroblasts. Invest Ophthalmol Vis Sci 47: 4895-4904.

Mezzano SA, Aros CA, Droguett A, Burgos ME, Ardiles LG, Flores CA, Carpio D, Vio CP, Ruiz-Ortega M, Egido J. 2003. Renal angiotensin II up-regulation and myofibroblast activation in human membranous nephropathy. Kidney Int Suppl 86: S39-S45. 
Miura M, El-Sawy T, Fairchild FL. 2003. Neutrophils mediate parenchymal tissue necrosis and accelerate the rejection of complete major histocompatibility complex-disparate cardiac allografts in the absence of interferon- $\gamma$. Am J Pathol 162: 509-519.

Molesworth-Kenyon SJ, Oakes JE, Lausch RN. 2005. A novel role for neutrophils as a source of T cell-recruiting chemokines IP-10 and Mig during the DTH response to HSV-1 antigen. J Leukoc Biol 77: 552-559.

Montgomery RA, Hardy MA, Jordan SC, Racusen LC, Ratner LE, Tyan DB, Zachary AA. 2004. Consensus opinion from the antibody working group on the diagnosis, reporting, and risk assessment for antibody-mediated rejection and desensitization protocols. Transplantation 78: 181-185.

Montgomery RA, Lonze BE, King KE, Kraus ES, Kucirka LM, Locke JE, Warren DS, Simpkins CE, Dagher NN, Singer AL, et al. 2011. Desensitization in HLA-incompatible kidney recipients and survival. $N$ Engl J Med 365: $318-326$.

Montgomery JR, Berger JC, Warren DS, James NT, Montgomery RA, Segev DL. 2012. Outcomes of ABO-incompatible kidney transplantation in the United States. Transplantation 93: 603-609.

Mosser DM, Edwards JP. 2008. Exploring the full spectrum of macrophage activation. Nat Rev Immunol 8: 958-969.

Moxham VF, Karegli J, Phillips RE, Brown KL, Tapmeier TT, Hangartner R, Sacks SH, Wong W. 2008. Homeostatic proliferation of lymphocytes results in augmented memory-like function and accelerated allograft rejection. J Immunol 180: 3910-3918.

Nadazdin O, Boskovic S, Murakami T, Tocco G, Smith RN, Colvin RB, Sachs DH, Allan J, Madsen JC, Kawai T, et al. 2011. Host alloreactive memory T cells influence tolerance to kidney allografts in nonhuman primates. Sci Transl Med 3: 86ra51.

Nafady-Hego H, Li Y, Ohe H, Zhao X, Satoda N, Sakaguchi S, Wood K, Uemoto S, Koshiba T. 2010. The generation of donor-specific $\mathrm{CD} 4{ }^{+} \mathrm{CD} 25^{2+} \mathrm{CD} 45 \mathrm{RA}^{+}$naive regulatory $\mathrm{T}$ cells in operationally tolerant patients after pediatric living-donor liver transplantation. Transplantation 90: 1547-1555.

Nankivell BJ, Borrows RJ, Fung CL, O'Connell PJ, Allen RD, Chapman JR. 2003. The natural history of chronic allograft nephropathy. N Engl J Med 349: 2326-2333.

Nelsestuen GL, Martinez MB, Hertz MI, Savik K, Wendt CH. 2005. Proteomic identification of human neutrophil $\alpha$-defensins in chronic lung allograft rejection. Proteomics 5: 1705-1713.

Neujahr DC, Perez SD, Mohammed A, Ulukpo O, Lawrence EC, Fernandez F, Pickens A, Force SD, Song M, Larsen CP, et al. 2012. Cumulative exposure to $\gamma$ interferon-dependent chemokines CXCL9 and CXCL10 correlates with worse outcome after lung transplant. Am J Transplant 12: $438-446$.

Newell KA, Asare A, Kirk AD, Gisler TD, Bourcier K, Suthanthiran M, Burlingham WJ, Marks WH, Sanz I, Lechler RI, et al. 2010. Identification of a B cell signature associated with renal transplant tolerance in humans. J Clin Invest 120: 1836-1847.

$\mathrm{Ng}$ YH, Oberbarnscheidt MH, Chandramoorthy HC, Hoffman R, Chalasani G. 2010. B cells help alloreactive T cells differentiate into memory T cells. Am J Transplant 10: 1970-1980.

Nickeleit V, Zeiler M, Gudat F, Thiel G, Mihatsch MJ. 2002. Detection of the complement degradation product C4d in renal allografts: Diagnostic and therapeutic implications. J Am Soc Nephrol 13: 242-251.

Niimi M, Hara M, Witzke O, Morris PJ, Wood KJ. 1998. Donor resting B cells induce indefinite prolongation of fully allogeneic cardiac grafts when delivered with antiimmunoglobulin-D monoclonal antibody: Evidence for tolerogenicity of donor resting B cells in vivo. Transplantation 66: 1786-1792.

Noorchashm H, Reed AJ, Rostami SY, Mozaffari R, Zekavat G, Koeberlein B, Caton AJ, Naji A. 2006. B cell-mediated antigen presentation is required for the pathogenesis of acute cardiac allograft rejection. J Immunol 177: 77157722.

Nozaki T, Amano H, Bickerstaff A, Orosz CG, Novick AC, Tanabe K, Fairchild RL. 2007. Antibody-mediated rejection of cardiac allografts in CCR5-deficient recipients. J Immunol 179: 5238-5245.

Ochando JC, Krieger NR, Bromberg JS. 2006. Direct versus indirect allorecognition: Visualization of dendritic cell distribution and interactions during rejection and tolerization. Am J Transplant 6: 2488-2496.

Ojo AO, Hanson JA, Wolfe RA, Leichtman AB, Agodoa LY, Port FK. 2000. Long-term survival in renal transplant recipients with graft function. Kidney Int 57: 307-313.

Ozawa M, Terasaki PI, Lee JH, Castro R, Alberu J, Alonso C, Alvarez I, Toledo R, Alvez H, Monterio M, et al. 2007. 14th International HLA and Immunogenetics Workshop: Report on the prospective chronic rejection project. Tissue Antigens 69: 174-179.

Paantjens AW, van de Graaf EA, Kwakkel-van Erp JM, Hoefnagel T, van Kessel DA, van den Bosch JM, Otten HG. 2011. Lung transplantation affects expression of the chemokine receptor type 4 on specific T cell subsets. Clin Exp Immunol 166: 103-109.

Pallier A, Hillion S, Danger R, Giral M, Racape M, Degauque N, Dugast E, Ashton-Chess J, Pettre S, Lozano JJ, et al. 2010. Patients with drug-free long-term graft function display increased numbers of peripheral $\mathrm{B}$ cells with a memory and inhibitory phenotype. Kidney Int 78: 503-513.

Panigrahi A, Siddiqui JA, Rai A, Margoob A, Khaira A, Bhowmik D, Tiwari SC, Guleria S, Mehra MK. 2007. Allosensitization to HLA and MICA is an important measure of renal graft outcome. Clin Transpl 2007: 211-217.

Pascual M, Theruvath T, Kawai T, Tolkoff-Rubin N, Cosimi AB. 2002. Strategies to improve long-term outcomes after renal transplantation. $N$ Engl J Med 346: 580-590.

Pearl JP, Parris J, Hale DA, Hoffmann SC, Bernstein WB, McCoy KL, Swanson SJ, Mannon RB, Roederer M, Kirk AD. 2005. Immunocompetent T-cells with a memorylike phenotype are the dominant cell type following antibody-mediated T-cell depletion. Am J Transplant 5: 465-474.

Pedagogos E, Hewitson TD, Walker RG, Nicholis KM, Becker GJ. 1997. Myofibroblast involvement in chronic transplant rejection. Transplantation 64: 1192-1197. 
A. Moreau et al.

Pei R, Lee JH, Shih NJ, Chen M, Terasaki PI. 2003. Single human leukocyte antigen flow cytometry beads for accurate identification of human leukocyte antigen antibody specificities. Transplantation 75: 43-49.

Perrella O, Sbreglia C, Arenga G, Perrella A, Ferrara A, D'Antonio A, Di Costanzo G, Atripaldi L, Alone C, Sciano D, et al. 2006. Acute rejection after liver transplantation: Is there a specific immunological pattern? Transplant Proc 38: 3594-3596.

Pilmore HL, Painter DM, Bishop GA, McCaughan GW, Eris JM. 2000. Early up-regulation of macrophages and myofibroblasts: A new marker for development of chronic renal allograft rejection. Transplantation 69: 2658-2662.

Pons JA, Revilla-Nuin B, Baroja-Mazo A, Ramirez P, Martinez-Alarcon L, Sanchez-Bueno F, Robles R, Rios A, Aparicio P, Parrilla P. 2008. FoxP3 in peripheral blood is associated with operational tolerance in liver transplant patients during immunosuppression withdrawal. Transplantation 86: $1370-1378$.

Port FK, Dykstra DM, Merion RM, Wolfe RA. 2004. Organ donation and transplantation trends in the USA, 2003. Am J Transplant 4: 7-12.

Posselt AM, Vincenti F, Bedolli M, Lantz M, Roberts JP, Hirose R. 2003. CD69 expression on peripheral CD8 T cells correlates with acute rejection in renal transplant recipients. Transplantation 76: 190-195.

Pratschke J, Stauch D, Kotsch K. 2009. Role of NK and NKT cells in solid organ transplantation. Transpl Int 22: 859868.

Qi F, Adair A, Ferenbach D, Vass DG, Mylonas KJ, Kipari T, Clay M, Kluth DC, Hughes J, Marson LP. 2008. Depletion of cells of monocyte lineage prevents loss of renal microvasculature in murine kidney transplantation. Transplantation 86: 1267-1274.

Racusen LC, Solez K, Colvin RB, Bonsib SM, Castro MC, Cavallo T, Croker BP, Demetris AJ, Drachenberg CB, Fogo $\mathrm{AB}$, et al. 1999. The Banff 97 working classification of renal allograft pathology. Kidney Int 55: 713-723.

Racusen LC, Colvin RB, Solez K, Mihatsch MJ, Halloran PF, Campbell PM, Cecka MJ, Cosyns JP, Demetris AJ, Fishbein MC, et al. 2003. Antibody-mediated rejection criteria-An addition to the Banff 97 classification of renal allograft rejection. Am J Transplant 3: 708-714.

Raedler H, Vieyra MB, Leisman S, Lakhani P, Kwan W, Yang M, Johnson K, Faas SJ, Tamburini P, Heeger PS. 2011. Anti-complement component C5 mAb synergizes with CTLA4Ig to inhibit alloreactive T cells and prolong cardiac allograft survival in mice. Am J Transplant 11: 1397 1406.

Raffetseder U, Rauen T, Djudjaj S, Kretzler M, En-Nia A, Tacke F, Zimmermann HW, Nelson PJ, Frye BC, Floege J, et al. 2009. Differential regulation of chemokine CCL5 expression in monocytes/macrophages and renal cells by Y-box protein-1. Kidney Int 75: 185-196.

Ramirez AM, Shen Z, Ritzenthaler JD, Roman J. 2006. Myofibroblast transdifferentiation in obliterative bronchiolitis: TGF- $\beta$ signaling through smad3-dependent and independent pathways. Am J Transplant 6: 2080-2088.

Ramsperger-Gleixner M, Spriewald BM, Tandler R, Kondruweit M, Amann K, Weyand M, Ensminger SM. 2011. Increased transcript levels of TNF- $\alpha$, TGF- $\beta$, and granzyme B in endomyocardial biopsies correlate with allograft rejection. Exp Clin Transplant 9: 387-392.

Rebellato LM, Ozawa M, Verbanac KM, Catrou P, Haisch CE, Terasaki PI. 2006. Clinical and anti-HLA antibody profile of nine renal transplant recipients with failed grafts: Donor-specific and non-donor-specific antibody development. Clin Transpl 2006: 241-253.

Regele H, Bohmig GA, Habicht A, Gollowitzer D, Schillinger M, Rockenschaub S, Watschinger B, Kerjaschki D, Exner M. 2002. Capillary deposition of complement split product $\mathrm{C} 4 \mathrm{~d}$ in renal allografts is associated with basement membrane injury in peritubular and glomerular capillaries: A contribution of humoral immunity to chronic allograft rejection. J Am Soc Nephrol 13: 23712380.

Ridge JP, Di Rosa F, Matzinger P. 1998. A conditioned dendritic cell can be a temporal bridge between a $\mathrm{CD} 4^{+} \mathrm{T}$ helper and a T-killer cell. Nature 393: 474-478.

Ro H, Hwang YH, Kim H, Jeong JC, Lee H, Doh YS, Park HC, Oh KH, Park MH, Ha J, et al. 2011. Association of polymorphisms of interleukin-8, CXCR1, CXCR2, and selectin with allograft outcomes in kidney transplantation. Transplantation 91: 57-64.

Rogers PR, Dubey C, Swain SL. 2000. Qualitative changes accompany memory $\mathrm{T}$ cell generation: Faster, more effective responses at lower doses of antigen. J Immunol 164: 2338-2346.

Roos-van Groningen MC, Scholten EM, Lelieveld PM, Rowshani AT, Baelde HJ, Bajema IM, Florquin S, Bemelman FJ, de Heer E, de Fijter JW, et al. 2006. Molecular comparison of calcineurin inhibitor-induced fibrogenic responses in protocol renal transplant biopsies. J Am Soc Nephrol 17: 881-888.

Rosenblum JM, Shimoda N, Schenk AD, Zhang H, Kish DD, Keslar K, Farber JM, Fairchild RL. 2010. CXC chemokine ligand CXCL9 and CXCL10 are antagonistic costimulation molecules during the priming of alloreactive $\mathrm{T}$ cell effectors. J Immunol 184: 3450-3460.

Rossini M, Cheunsuchon B, Donnert E, Ma LJ, Thomas JW, Neilson EG, Fogo AB. 2005. Immunolocalization of fibroblast growth factor-1 (FGF-1), its receptor (FGFR-1), and fibroblast-specific protein-1 (FSP-1) in inflammatory renal disease. Kidney Int 68: 2621-2628.

Rotondi M, Rosati A, Buonamano A, Lasagni L, Lazzeri E, Pradella F, Fossombroni V, Cirami C, Liotta F, La Villa G, et al. 2004. High pretransplant serum levels of CXCL10/ IP-10 are related to increased risk of renal allograft failure. Am J Transplant 4: 1466-1474.

Rotondi M, Netti GS, Lazzeri E, Stallone G, Bertoni E, Chiovato L, Grandaliano G, Gesualdo L, Salvadori M, Schena FP, et al. 2010. High pretransplant serum levels of CXCL9 are associated with increased risk of acute rejection and graft failure in kidney graft recipients. Transpl Int 23: 465-475.

Sagoo P, Perucha E, Sawitzki B, Tomiuk S, Stephens DA, Miqueu P, Chapman S, Craciun L, Sergeant R, Brouard S, et al. 2010. Development of a cross-platform biomarker signature to detect renal transplant tolerance in humans. J Clin Invest 120: 1848-1861.

Sagoo P, Ali N, Garg G, Nestle FO, Lechler RI, Lombardi G. 2011. Human regulatory $\mathrm{T}$ cells with alloantigen specificity are more potent inhibitors of alloimmune skin graft 
damage than polyclonal regulatory T cells. Sci Transl Med 3: 83 ra42.

Salama AD, Womer KL, Sayegh MH. 2007. Clinical transplantation tolerance: Many rivers to cross. J Immunol 178: $5419-5423$

Sallusto F, Lenig D, Forster R, Lipp M, Lanzavecchia A. 1999. Two subsets of memory $\mathrm{T}$ lymphocytes with distinct homing potentials and effector functions. Nature 401: $708-712$.

Sarma NJ, Tiriveedhi V, Angaswamy N, Mohanakumar T. 2012. Role of antibodies to self-antigens in chronic allograft rejection: Potential mechanism and therapeutic implications. Hum Immunol 10: 10.

Schaub S, Nickerson P, Rush D, Mayr M, Hess C, Golian M, Stefura W, Hayglass K. 2009. Urinary CXCL9 and CXCL10 levels correlate with the extent of subclinical tubulitis. Am J Transplant 9: 1347-1353.

Schluns KS, Kieper WC, Jameson SC, Lefrancois L. 2000. Interleukin-7 mediates the homeostasis of naive and memory CD8 T cells in vivo. Nat Immunol 1: 426-432.

Schowengerdt KO, Fricker FJ, Bahjat KS, Kuntz ST. 2000. Increased expression of the lymphocyte early activation marker CD69 in peripheral blood correlates with histologic evidence of cardiac allograft rejection. Transplantation 69: 2102-2107.

Seiler M, Brabcova I, Viklicky O, Hribova P, Rosenberger C, Pratschke J, Lodererova A, Matz M, Schonemann C, Reinke P, et al. 2007. Heightened expression of the cytotoxicity receptor NKG2D correlates with acute and chronic nephropathy after kidney transplantation. Am J Transplant 7: 423-433.

Shenoy KV, Solomides C, Cordova F, Rogers TJ, Ciccolella D, Criner GJ. 2012. Low CD4/CD8 ratio in bronchus-associated lymphoid tissue is associated with lung allograft rejection. J Transplant 2012: 928081.

Shevach EM. 2009. Mechanisms of FoxP3 $3^{+}$Tregulatory cellmediated suppression. Immunity 30: 636-645.

Shin GT, Kim SJ, Lee TS, Oh CK, Kim H. 2005. Gene expression of perforin by peripheral blood lymphocytes as a marker of acute rejection. Nephron Clin Pract 100: c63c70.

Silva HM, Takenaka MC, Moraes-Vieira PM, Monteiro SM, Hernandez MO, Chaara W, Six A, Agena F, Sesterheim P, Barbe-Tuana FM, et al. 2012. Preserving the B-cell compartment favors operational tolerance in human renal transplantation. Mol Med 18: 733-743.

Sis B, Campbell PM, Mueller T, Hunter C, Cockfield SM, Cruz J, Meng C, Wishart D, Solez K, Halloran PF. 2007. Transplant glomerulopathy, late antibody-mediated rejection and the ABCD tetrad in kidney allograft biopsies for cause. Am J Transplant 7: 1743-1752.

Sis B, Jhangri GS, Bunnag S, Allanach K, Kaplan B, Halloran PF. 2009. Endothelial gene expression in kidney transplants with alloantibody indicates antibody-mediated damage despite lack of C4d staining. Am J Transplant 9: 2312-2323.

Smith C, Miles JJ, Khanna R. 2012. Advances in direct T-cell alloreactivity: Function, avidity, biophysics and structure. Am J Transplant 12: 15-26.

Smyth LA, Herrera OB, Golshayan D, Lombardi G, Lechler RI. 2006. A novel pathway of antigen presentation by dendritic and endothelial cells: Implications for allorecognition and infectious diseases. Transplantation 82: S15-S18.

Solez K, Vincenti F, Filo RS. 1998. Histopathologic findings from 2-year protocol biopsies from a U.S. multicenter kidney transplant trial comparing tarolimus versus cyclosporine: A report of the FK506 Kidney Transplant Study Group. Transplantation 66: 1736-1740.

Solez K, Colvin RB, Racusen LC, Sis B, Halloran PF, Birk PE, Campbell PM, Cascalho M, Collins AB, Demetris AJ, et al. 2007. Banff '05 meeting report: Differential diagnosis of chronic allograft injury and elimination of chronic allograft nephropathy ("CAN"). Am J Transplant 7: $518-526$.

Solez K, Colvin RB, Racusen LC, Haas M, Sis B, Mengel M, Halloran PF, Baldwin W, Banfi G, Collins AB, et al. 2008. Banff 07 classification of renal allograft pathology: Updates and future directions. Am J Transplant 8: 753-760.

Sommer M, Gerth J, Stein G, Wolf G. 2005. Transdifferentiation of endothelial and renal tubular epithelial cells into myofibroblast-like cells under in vitro conditions: A morphological analysis. Cells Tissues Organs 180: 204-214.

Sorrentino C, Scarinci A, D’Antuono T, Piccirilli M, Di Nicola M, Pasquale M, Di Iorio C, Di Carlo E. 2006. Endomyocardial infiltration by B and NK cells foreshadows the recurrence of cardiac allograft rejection. J Pathol 209: 400-410.

Sumitran-Holgersson S. 2008. Relevance of MICA and other non-HLA antibodies in clinical transplantation. Curr Opin Immunol 20: 607-613.

Sumitran-Holgersson S, Wilczek HE, Holgersson J, Soderstrom K. 2002. Identification of the nonclassical HLA molecules, mica, as targets for humoral immunity associated with irreversible rejection of kidney allografts. Transplantation 74: 268-277.

Summers AM, Coupes BM, Brennan MF, Ralph SA, Short CD, Brenchley PE. 2005. VEGF-460 genotype plays an important role in progression to chronic kidney disease stage 5. Nephrol Dial Transplant 20: 2427-2432.

Sun HJ, Zhou T, Wang Y, Fu YW, Jiang YP, Zhang LH, Zhang CB, Zhou HL, Gao BS, Shi YA, et al. 2011. Macrophages and $\mathrm{T}$ lymphocytes are the predominant cells in intimal arteritis of resected renal allografts undergoing acute rejection. Transpl Immunol 25: 42-48.

Surquin M, Le Moine A, Flamand V, Rombaut K, Demoor FX, Salmon I, Goldman M, Abramowicz D. 2005. IL-4 deficiency prevents eosinophilic rejection and uncovers a role for neutrophils in the rejection of MHC class II disparate skin grafts. Transplantation 80: 1485-1492.

Taflin C, Favier B, Baudhuin J, Savenay A, Hemon P, Bensussan A, Charron D, Glotz D, Mooney N. 2011. Human endothelial cells generate Th17 and regulatory T cells under inflammatory conditions. Proc Natl Acad Sci 108: $2891-2896$

Taflin C, Charron D, Glotz D, Mooney N. 2012. Regulation of the $\mathrm{CD} 4^{+} \mathrm{T}$ cell allo-immune response by endothelial cells. Hum Immunol 16: 16.

Takeiri M, Tachibana M, Kaneda A, Ito A, Ishikawa Y, Nishiyama S, Goto R, Yamashita K, Shibasaki S, Hirokata G, et al. 2011. Inhibition of macrophage activation and suppression of graft rejection by DTCM-glutarimide, a novel 
A. Moreau et al.

piperidine derived from the antibiotic 9-methylstreptimidone. Inflamm Res 60: 879-888.

Tanaka K, Ozawa K, Teramukai S, Takada Y, Egawa H, Kaihara S, Fujimoto Y, Ogura Y, Kasahara M, Ono M, et al. 2006. Classification of human liver transplant recipients by their preoperative $\mathrm{CD}^{+} \mathrm{T}$ cell subpopulation and its relation to outcome. Liver Transpl 12: 792-800.

Tatapudi RR, Muthukumar T, Dadhania D, Ding R, Li B, Sharma VK, Lozada-Pastorio E, Seetharamu N, Hartono C, Serur D, et al. 2004. Noninvasive detection of renal allograft inflammation by measurements of mRNA for IP-10 and CXCR3 in urine. Kidney Int 65: 2390-2397.

Terasaki PI. 2003. Humoral theory of transplantation. Am J Transplant 3: 665-673.

Terasaki PI, Cai J. 2005. Humoral theory of transplantation: Further evidence. Curr Opin Immunol 17: 541-545.

Terasaki PI, Ozawa M. 2004. Predicting kidney graft failure by HLA antibodies: A prospective trial. Am J Transplant 4 $438-443$.

Thaunat O, Nicoletti A. 2008. Lymphoid neogenesis in chronic rejection. Curr Opin Organ Transplant 13: $16-$ 19.

Thaunat O, Field AC, Dai J, Louedec L, Patey N, Bloch MF, Mandet C, Belair MF, Bruneval P, Meilhac O, et al. 2005 Lymphoid neogenesis in chronic rejection: Evidence for a local humoral alloimmune response. Proc Natl Acad Sci 102: $14723-14728$.

Thaunat O, Patey N, Morelon E, Michel JB, Nicoletti A. 2006. Lymphoid neogenesis in chronic rejection: The murderer is in the house. Curr Opin Immunol 18: 576579.

Thaunat O, Patey N, Gautreau C, Lechaton S, FremeauxBacchi V, Dieu-Nosjean MC, Cassuto-Viguier E, Legendre C, Delahousse M, Lang P, et al. 2008. B cell survival in intragraft tertiary lymphoid organs after rituximab therapy. Transplantation 85: 1648-1653.

Thaunat O, Graff-Dubois S, Brouard S, Gautreau C, Varthaman A, Fabien N, Field AC, Louedec L, Dai J, Joly E, et al. 2010. Immune responses elicited in tertiary lymphoid tissues display distinctive features. PLoS ONE 5: e11398.

Thaunat O, Graff-Dubois S, Fabien N, Duthey A, AttuilAudenis V, Nicoletti A, Patey N, Morelon E. 2012. A stepwise breakdown of B-cell tolerance occurs within renal allografts during chronic rejection. Kidney Int 81: 207-219.

Tyden G, Genberg H, Tollemar J, Ekberg H, Persson NH, Tufveson G, Wadstrom J, Gabel M, Mjornstedt L. 2009. A randomized, doubleblind, placebo-controlled, study of single-dose rituximab as induction in renal transplantation. Transplantation 87: 1325-1329.

Uppaluri R, Sheehan KC, Wang L, Bui JD, Brotman JJ, Lu B, Gerard C, Hancock WW, Schreiber RD. 2008. Prolongation of cardiac and islet allograft survival by a blocking hamster anti-mouse CXCR3 monoclonal antibody. Transplantation 86: 137-147.

Valujskikh A, Pantenburg B, Heeger PS. 2002. Primed allospecific $T$ cells prevent the effects of costimulatory blockade on prolonged cardiac allograft survival in mice. Am J Transplant 2: 501-509.

Van der Touw W, Burrell B, Lal G, Bromberg JS. 2012. NK cells are required for costimulatory blockade induced tolerance to vascularized allografts. Transplantation 20: 20.

Veiga-Fernandes H, Walter U, Bourgeois C, McLean A, Rocha B. 2000. Response of naive and memory $\mathrm{CD}^{+} \mathrm{T}$ cells to antigen stimulation in vivo. Nat Immunol 1: 47-53.

Wang Y, Dai H, Liu Z, Cheng X, Tellides G, Dai Z. 2006. Neutralizing IL-7 promotes long-term allograft survival induced by $\mathrm{CD} 40 / \mathrm{CD} 40 \mathrm{~L}$ costimulatory blockade. Am $J$ Transplant 6: 2851-2860.

Wang S, Li J, Xie A, Wang G, Xia N, Ye P, Rui L, Xia J. 2011. Dynamic changes in Th1, Th17, and FoxP3 ${ }^{+} \mathrm{T}$ cells in patients with acute cellular rejection after cardiac transplantation. Clin Transplant 25: E177-E186.

Wasowska BA, Qian Z, Cangello DL, Behrens E, Van Tran K, Layton J, Sanfilippo F, Baldwin MW III. 2001. Passive transfer of alloantibodies restores acute cardiac rejection in IgKO mice. Transplantation 71: 727-736.

Won DI, Jeong HD, Kim YL, Suh JS. 2006. Simultaneous detection of antibody binding and cytotoxicity in flow cytometry crossmatch for renal transplantation. Cytometry B Clin Cytom 70: 82-90.

Wu Z, Bensinger SJ, Zhang J, Chen C, Yuan X, Huang X, Markmann JF, Kassaee A, Rosengard BR, Hancock WW, et al. 2004. Homeostatic proliferation is a barrier to transplantation tolerance. Nat Med 10: 87-92.

Wu T, Bond G, Martin D, Nalesnik MA, Demetris AJ, Abu-Elmagd K. 2006. Histopathologic characteristics of human intestine allograft acute rejection in patients pretreated with thymoglobulin or alemtuzumab. $A m J$ Gastroenterol 101: 1617-1624.

Wynn TA. 2008. Cellular and molecular mechanisms of fibrosis. J Pathol 214: 199-210.

Xu H, Zhang X, Mannon RB, Kirk AD. 2006. Platelet-derived or soluble CD154 induces vascularized allograft rejection independent of cell-bound CD154. J Clin Invest 116: 769-774.

Yabu JM, Higgins JP, Chen G, Sequeira F, Busque S, Tyan DB. 2011. C1q-fixing human leukocyte antigen antibodies are specific for predicting transplant glomerulopathy and late graft failure after kidney transplantation. Transplantation 91: 342-347.

Yamada A, Salama AD, Sho M, Najafian N, Ito T, Forman JP, Kewalramani R, Sandner S, Harada H, Clarkson MR, et al. 2005. CD70 signaling is critical for CD28-independent $\mathrm{CD}^{+} \mathrm{T}$ cell-mediated alloimmune responses in vivo. J Immunol 174: 1357-1364.

Yang WS, Han NJ, Kim CS, Ahn H, Lee SK, Lee KU, Park SK. 2005. STAT1-independent down-regulation of interferon- $\gamma$-induced class II transactivator and HLA-DR expression by transforming growth factor $\beta-1$ in human glomerular endothelial cells. Nephron Exp Nephrol 100: e124-e131.

Yoo S, Lee EY, Huh KH, Kim MS, Kim YS, Kim HO. 2012. Role of plasma exchange in ABO-incompatible kidney transplantation. Ann Lab Med 32: 283-288.

Yuan X, Dong VM, Coito AJ, Waaga AM, Salama AD, Benjamin CD, Sayegh MH, Chandraker A. 2002. A novel CD154 monoclonal antibody in acute and chronic rat vascularized cardiac allograft rejection. Transplantation 73: $1736-1742$. 
Yuan X, Paez-Cortez J, Schmitt-Knosalla I, D’Addio F, Mfarrej B, Donnarumma M, Habicht A, Clarkson MR, Iacomini J, Glimcher LH, et al. 2008. A novel role of CD4 Th17 cells in mediating cardiac allograft rejection and vasculopathy. J Exp Med 205: 3133-3144.

Yuan X, Ansari MJ, D’Addio F, Paez-Cortez J, Schmitt I, Donnarumma M, Boenisch O, Zhao X, Popoola J, Clarkson MR, et al. 2009. Targeting Tim-1 to overcome resistance to transplantation tolerance mediated by CD8 T17 cells. Proc Natl Acad Sci 106: 10734-10739.

Zafar MN, Terasaki PI, Naqvi SA, Rizvi SA. 2006. Non-HLA antibodies after rejection of HLA identical kidney transplants. Clin Transpl 2006: 421-426.

Zarkhin V, Chalasani G, Sarwal MM. 2010. The yin and yang of B cells in graft rejection and tolerance. Transplant Rev (Orlando) 24: 67-78.

Zhai Y, Meng L, Gao F, Busuttil RW, Kupiec-Weglinski JW. 2002. Allograft rejection by primed/memory $\mathrm{CD}^{+} \mathrm{T}$ cells is CD154 blockade resistant: Therapeutic implications for sensitized transplant recipients. J Immunol 169: $4667-4673$
Zhai Y, Shen XD, Hancock WW, Gao F, Qiao B, Lassman C, Belperio JA, Strieter RM, Busuttil RW, Kupiec-Weglinski JW. 2006. CXCR $3^{+} \mathrm{CD}^{+}{ }^{+} \mathrm{T}$ cells mediate innate immune function in the pathophysiology of liver ischemia/reperfusion injury. J Immunol 176: 6313-6322.

Zhang ZX, Wang S, Huang X, Min WP, Sun H, Liu W, Garcia B, Jevnikar AM. 2008. NK cells induce apoptosis in tubular epithelial cells and contribute to renal ischemiareperfusion injury. J Immunol 181: 7489-7498.

Zhou W, Farrar CA, Abe K, Pratt JR, Marsh JE, Wang Y, Stahl GL, Sacks SH. 2000. Predominant role for C5b-9 in renal ischemia/reperfusion injury. J Clin Invest 105: $1363-$ 1371.

Zhuo M, Fujiki M, Wang M, Piard-Ruster K, Wai LE, Wei L, Martinez OM, Krams SM. 2010. Identification of the rat NKG2D ligands, RAE1L and RRLT, and their role in allograft rejection. Eur J Immunol 40: 1748-1757.

Zou Y, Stastny P, Susal C, Dohler B, Opelz G. 2007. Antibodies against MICA antigens and kidney-transplant rejection. N Engl J Med 357: 1293-1300. 


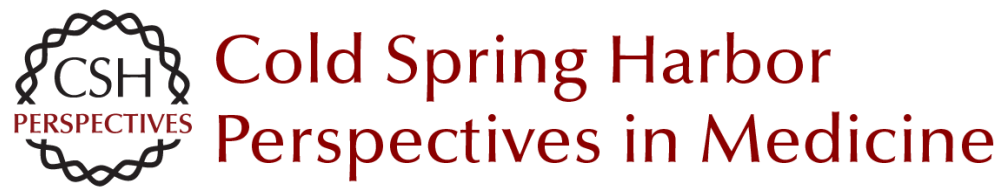

\section{Effector Mechanisms of Rejection}

Aurélie Moreau, Emilie Varey, Ignacio Anegon and Maria-Cristina Cuturi

Cold Spring Harb Perspect Med 2013; doi: 10.1101/cshperspect.a015461

Subject Collection Transplantation

Heart Transplantation: Challenges Facing the Field

Makoto Tonsho, Sebastian Michel, Zain Ahmed, et al.

Bioethics of Organ Transplantation Arthur Caplan

Overview of Clinical Lung Transplantation Jonathan C. Yeung and Shaf Keshavjee

Immunological Challenges and Therapies in

Xenotransplantation Marta Vadori and Emanuele Cozzi

Clinical Aspects: Focusing on Key Unique Organ-Specific Issues of Renal Transplantation Sindhu Chandran and Flavio Vincenti

T-Cell Costimulatory Blockade in Organ

Transplantation Jonathan S. Maltzman and Laurence A. Turka

Regulatory T-Cell Therapy in Transplantation: Moving to the Clinic

Qizhi Tang and Jeffrey A. Bluestone

Opportunistic Infections--Coming to the Limits of Immunosuppression?

Jay A. Fishman
Overview of the Indications and Contraindications for Liver Transplantation

Stefan Farkas, Christina Hackl and Hans Jürgen Schlitt

Facial and Hand Allotransplantation Bohdan Pomahac, Ryan M. Gobble and Stefan Schneeberger

Induction of Tolerance through Mixed Chimerism David H. Sachs, Tatsuo Kawai and Megan Sykes

Pancreas Transplantation: Solid Organ and Islet Shruti Mittal, Paul Johnson and Peter Friend

Tolerance--Is It Worth It? Erik B. Finger, Terry B. Strom and Arthur J. Matas

Lessons and Limits of Mouse Models Anita S. Chong, Maria-Luisa Alegre, Michelle L. Miller, et al.

Effector Mechanisms of Rejection Aurélie Moreau, Emilie Varey, Ignacio Anegon, et al.

The Innate Immune System and Transplantation Conrad A. Farrar, Jerzy W. Kupiec-Weglinski and Steven H. Sacks

For additional articles in this collection, see http://perspectivesinmedicine.cshlp.org/cgi/collection/ 